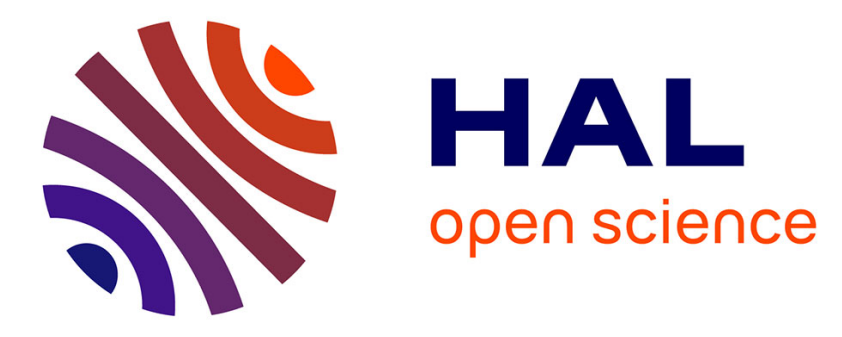

\title{
Humusica 2, article 16: Techno humus systems and recycling of waste
}

Augusto Zanella, Jean-François Ponge, Stefano Guercini, Clelia Rumor, François Nold, Paolo Sambo, Valentina Gobbi, Claudia Schimmer, Catherine Chaabane, Marie-Laure Mouchard, et al.

\section{To cite this version:}

Augusto Zanella, Jean-François Ponge, Stefano Guercini, Clelia Rumor, François Nold, et al.. Humusica 2, article 16: Techno humus systems and recycling of waste. Applied Soil Ecology, 2018, 122 (Part 2), pp.220 - 236. 10.1016/j.apsoil.2017.09.037 . hal-01668155

\section{HAL Id: hal-01668155 https://hal.science/hal-01668155}

Submitted on 19 Dec 2017

HAL is a multi-disciplinary open access archive for the deposit and dissemination of scientific research documents, whether they are published or not. The documents may come from teaching and research institutions in France or abroad, or from public or private research centers.
L'archive ouverte pluridisciplinaire HAL, est destinée au dépôt et à la diffusion de documents scientifiques de niveau recherche, publiés ou non, émanant des établissements d'enseignement et de recherche français ou étrangers, des laboratoires publics ou privés. 


\title{
Humusica 2, article 16: Techno humus systems and recycling of waste
}

\author{
Augusto Zanella ${ }^{a^{*}}$, Jean-François Ponge ${ }^{b}$, Stefano Guercini ${ }^{a}$, Clelia Rumor ${ }^{a}$, François Nold ${ }^{c}$, Paolo \\ Sambo ${ }^{a}$, Valentina Gobbi ${ }^{a}$, Claudia Schimmer ${ }^{d}$, Catherine Chaabane ${ }^{c}$, Marie-Laure Mouchard ${ }^{c}$, Elena \\ Garcia $^{c}$, Piet van Deventer ${ }^{\mathrm{d}}$ \\ ${ }^{a}$ University of Padua, Italy \\ ${ }^{\mathrm{b}}$ Muséum National d'Histoire Naturelle, Paris, France \\ ${ }^{\mathrm{c}}$ Mairie de Paris, Laboratoire d'Agronomie, France \\ ${ }^{\mathrm{d}}$ Northwest University, Potchefstroom, South Africa
}

\section{ABSTRACT}

Techno humus systems correspond to man-made topsoils under prominent man influence. They may be purposely conceived for supporting agricultural activities or dumping of waste products, sometimes abandoned to an unknown evolution. Both categories needed a more scientific frame. This is the reason we classified them as morpho-functional humus systems. Improving agricultural soils with organic waste products is an ancestral practice. We present four examples of Techno humus systems purposely created for supporting plant growth. Considering a simple home-made compost pile, we give a few basic notions about the biological functioning of these artificial humus systems. Humipedon functioning and structuration are similar to those observed in natural humus systems. Using even animal manure, we illustrate how to manage larger compost piles of waste for application in farming areas. Composting waste that contains animal proteins needs a more careful measurement of the temperature of the pile and a longer period of elevated temperature in the core of the pile. Mulching of pruning residues is presented in a large urban context. The use of mulch must take into account the quality and composition of woody material. The lack of nutrients in some residues has to be compensated by a moderate use of appropriate mineral fertilizers. Municipal solid waste, anaerobic digestion residues (grape remains) and spent mushroom compost, eventually mixed with mineral fertilizers, have been tested in horticulture. Benefits and drawbacks are listed for each experiment, with the evolution of carbon storage along 8 years of horticultural practice. Finally, we present an example of "dump" humus system. Mine tailing wastes represent a huge problem in many countries. Pointing to their microbial activity, we show that they must be seen as manageable living humipedons, not as piles of inert rocky material.

\footnotetext{
* Corresponding author.

E-mail addresses: augusto.zanella@unipd.it (A. Zanella), ponge@mnhn.fr (J.-F. Ponge), stefano.guercini@unipd.it (S. Guercini), cleliarumor@libero.it (C. Rumor), francois.nold@paris.fr (F. Nold), paolo.sambo@unipd.it (P. Sambo), valentina.gobbi@unipd.it (V. Gobbi), claudia.schimmer8@gmail.com (C. Schimmer), catherine.chaabane@paris.fr (C. Chaabane), marie-laure.mouchard@paris.fr (M.-L. Mouchard), elena.garcia@paris.fr (E. Garcia), piet.vandeventer@nwu.ac.za (P.van Deventer).
} 


\section{Main Groups of Techno systems}

Techno humus systems or techno humus horizons correspond to artificial humus systems and horizons under prominent man influence. Three main groups of Techno systems can be individuated:

- Manure humus systems: techno humus systems with soil, imitating natural humipedons and created for supporting plants and ecosystems. Man has to prepare remains for feeding soil organisms and to take care of the natural biological transformation of these remains. Soil organisms will automatically transform the remains and thus generate a new soil. Feeding soil organisms with organic remains mimics what occurs in natural ecosystems where organic dead structures (e.g. leaves, dead organisms) continuously feed the soil and its trophic networks even in anaerobic circumstances (digestates);

- Soil-free humus systems: techno humus systems without soil. Man has to prepare nutrient solutions for specific plant species or plant communities. Each plant or culture has its own nutrient demand. Plant roots grow directly in a solution or in a more or less inert medium in which a nutrient solution circulate. Organic matter decomposition and soil formation are avoided. The target is to support specific plant growth and/or fruit or legume production, following the variable nutrient demand of plants along the planned cycle of production. A similar process occurs in aquatic environments with floating vegetation. Man adapted this type of nutrition to plants that naturally grow in the soil. Strong mechanisation and control of chemical and physical factors are necessary for a cost-effective production. Disease control is facilitated by the physical confinement of the cultures. Use of pesticides is the rule, treating locally each plant or group of infected plants or preventing them from infection because cultivated plants are more fragile. Stratification and verticalization of artificial production systems are commonly adopted in greenhouses or outdoor (Lowenfels, 2017; Rech, 2013). Productivity is always higher than in soil cultures, especially for tomato, cucumber, pepper, eggplant, lettuce and some aromatic herbs because secondary metabolism is decreased in favour of primary (growth) metabolism. However, because of the lack of complex soil nutrients and the absence of parasites (which in natural environments force plants to produce aromatic defence molecules), hydroponic plant tissues, fruits and legumes are beautiful to see but often less tasty than those cultivated in soil and far less than those coming from organic farming (this topic is discussed in Humusica 2, article 17). Nevertheless, hydroponic techniques allow growing plants without soil and considerably decrease production costs. Some scientists strongly support hydroponic food production (Rech, 2013, see also http://howardresh.com/), while others are far less favourable due to the high need for plant protection products (Hatzilazarou et al., 2005, see also http://www.arc.agric.za/arcvopi/Pages/Crop\%20Science/Hydroponic-VegetableProduction.aspx).

- Dump humus systems: techno humus systems or horizons not purposely created for supporting plants and ecosystems, more or less controlled, or contained, or circumscribed for avoiding pollution. They generally correspond to dumping of waste, which can be a source of energy for soil organisms and start a process of soil formation. Examples: sewage 
sludge, dumps, toxic waste, landfill waste, colonized masonry waste, other abandoned topsoils or recycling waste or biodegrading materials.

This article is mainly dedicated to manure humus systems. After comparing the functioning of natural and techno humus systems, we will illustrate a home-made system. This simple system allows better understanding the structure of a techno humus system, before showing results of a series of experiments performed in Agripolis (Italy) and Paris (France) with the aim of using large amounts of organic remains. We will jump from the treatment of family organic remains for home gardening, to larger areas and applications to agriculture and horticulture, considering different types of compost and mulch. Even if we are conscious of their economic importance, we do not consider soil-free humus systems in this paper. The reason is that we support the use of biologically rich humus systems for agricultural and horticultural purposes (more in-depth analysis in Humusica 2, articles 17, 18 and 19). The present article concludes with an investigation of the dump humus system hold in South Africa by a team from the North-West University of Potchefstroom. To have an expert knowledge of this type of humus system is obviously necessary in order to avoid ecological failures and public health troubles.

1.1. Manure humus systems: techno humus systems with soil created for supporting plants and ecosystems

Structure and functioning of manure techno humus systems are similar to those presented in Humusica 1 articles for natural Terrestrial humus systems (Mull, Moder and Amphi). Comparing artificial with natural humus systems is a good mean of better understanding soil functioning and eventually intervening for improving soil quality. With the word "compost" we commonly name a pile of organic remains under decomposition or even the intermediate or final result of the process of decomposition. Wanting to be more precise, we name "humus system" a pile of organic remains only when it begins to structure itself in humus horizons. Before acquiring a new structure, as the fruit of a process of decomposition, the pile of organic remains is not a natural humus system but just a heap of "litter". It is possible to accelerate the process of biodegradation, mix thus formed horizons, adding new material, aerating the pile and destroying/orienting/modifying a natural system in formation. With these operations, farmers and gardeners purposely interfere with the natural process of organic matter decomposition and transform natural humus systems into Techno humus systems (Mustin, 1987; Culot and Lebeau, 1999; Tuomela et al., 2000; Ouédraogo et al., 2001; Fontaine et al., 2003; Annabi et al., 2005; Ros et al., 2006; Saison et al., 2006; Evanylo et al., 2008; Adani et al., 2009; Lowenfels and Lewis, 2010; Brown and Cotton, 2011; Zhao et al., 2013; Lowenfels, 2014; Gerbier, 2015; Kuzyakov and Blagodatskaya, 2015; Lowenfels, 2017).

The word "mulch" is used when the decomposing pile of organic remains is made of wood or bark chips (dimensions: from a $\mathrm{mm}$ to a few $\mathrm{cm}$ ). At the beginning of the process of decomposition, mulch corresponds to woody litter. It becomes woody $\mathrm{OF}$ and $\mathrm{OH}$ horizons in a further step, finishing its transformation into organic-mineral aggregates (A horizon) as other non-woody techno humus systems. The natural transformation of woody litter is presented in Humusica 2, article 13, in a 
section dedicated to Ligno humus systems. In Humusica 3, D. Tatti and collaborators detail their description and classification in a paper entitled "What does 'lignoform' really mean?"

Compared to natural humus systems, made of a series of relatively thin horizons, from fresh litter till highly biodegraded organic matter, manured Techno humus systems are generally thicker and diagnostic horizons are less visible and eventually are evident only between phases of artificial mixing. As in natural topsoils, in manure humus systems humus horizons are formed as a result of biological activity. Animals occupy different habitats/niches and are distributed in the accumulated organic remains in accordance with their specific needs: large detritivores on larges pieces of litter at the top, smaller animals on finer material in deeper layers (Huhta et al., 1979). Animal and microbial communities are disturbed and less abundant and diversified in artificial than in natural humus systems at the beginning of the process of biodegradation but they evolve towards more complete and near-natural communities in the course of time (Huhta et al., 1979; de Bertoldi et al., 1983; Tiquia , 2005). Being continuously fed, animal and microbial communities may develop without any constraints, humifying and mineralizing large amounts of organic remains in a few months. The pile works like an artificial very active Mull, continuously fed with fresh litter and mechanically aerated by periodically turning down the organic mass under biodegradation.

At the beginning of the process of decomposition, the artificial pile is essentially made of fresh litter (organic remains, OL horizon). The layer of fresh litter is commonly one metre thick in domestic composters while in composting plants windrows can reach a thickness of a few metres and a linear extent of a dozen meters. In comparison, in natural conditions litter rarely reaches a thickness of $10 \mathrm{~cm}$ and is spread over the whole surface of the ecosystem (forest, meadow, etc.).

Because a high volume of accumulated litter impedes natural oxygenation large artificial compost heaps need being periodically manually or mechanically aerated, moving the layers top down and creating tunnels in order to allow air reaching the core of the pile. In fact, the core often lacks oxygen, because of the intense respiratory metabolism of microorganisms in the warm and most environment of the climatically protected core (Körner et al., 2003). A right content in "skeletal" material, such as twigs, pieces of wood or cardboard, helps giving the compost an aerated structure comparable to what soil animals and microbes find in natural humipedons. During the process of biological oxidation, part of the energy that fixes the atoms of carbon in organic macromolecules is released as radiant energy which, by dissipating itself through the mass of litter, increases the temperature. Under decomposition the temperature of a cubic meter of litter easily rises to $50-70^{\circ} \mathrm{C}$ in its core part (Sommer and Dahl, 1999). The optimum temperature of the core for a fast biodegradation ensuring a good quality to the produced compost is $50-60^{\circ} \mathrm{C}$. If well controlled, this phenomenon can sterilise temporarily the pile of material, avoiding the proliferation of undesired microorganisms (mostly pathogens) and destroying unwanted weed seeds (Bollen et al., 1989). National laws regulate compost production and commercialisation. For obvious reasons of public health, well-known groups of microorganisms, in particular human pathogens, must be absent or fixed under prescribed limits before compost can be used in horticulture or agriculture. A guideline for compost quality is available at: http://www.ccme.ca/files/Resources/waste/compost quality/compostgdlns 1340 e.pdf.

Here down the reader will find a list of elementary notions for people wanting to compost a pile of organic materials. All Humusica articles were written with the aim to stimulate people to 
understand and use the soil as a friendly living ecosystem. This approximate information cannot substitute more scientific publications. We suggest referring to Lowenfels $(2017,2014)$ and Lowenfels and Lewis (2010) for examples of management of soil biodiversity for gardening targets. The best way to learn how to use soil biodiversity is to care the soil as if it were a living macroorganism, a domesticated "giant amoeba" you feed for obtaining in return good food and water for sustaining human life. Being linked to a community of farmers is also a very useful initiative (examples: http://www.aiab.it/; http://www.fnab.org/; https://www.organicconsumers.org/; http://wwoofinternational.org/):

- A large amount of the weight of fresh organic matter is made of water $\left(\mathrm{H}_{2} \mathrm{O}\right)$ : fruits and legumes content $60-90 \%$ of water; woody material meanly contents $30 \%$ of free and $30 \%$ bound water; depending on plant species, a dry piece of wood can lose from 30 to $200 \%$ of its dry weight in the form of water;

- Soil organic matter is approximately composed (in weight) of $50 \%$ carbon, $40 \%$ oxygen, $5 \%$ hydrogen, $4 \%$ nitrogen, $1 \%$ other elements (Schumacher et al., 2006);

- The mean $\mathrm{C} / \mathrm{N}$ ratio of organic remains is equal to 30 . This means that the content in $\mathrm{C}$ is 30 times that of $\mathrm{N}$. C:N:P ratios in both soil (186:13:1) and soil microbial biomass (60:7:1) are well-constrained at global scale (Cleveland and Liptzin, 2007), i.e. in average a C content 10 times larger than $\mathrm{N}$ (three times lower than in organic remains);

- Behind the word "biodegradation" there are two combined processes: catabolism and anabolism. The former can be put in synonymy with "respiration" (a process of controlled oxidation also called "mineralisation", literally destruction of structures until their mineral components separate). It liberates energy, partially dissipated as heat (the temperature of the pile increases during the process), the remaining part being used in a build-up process, creating new organic matter (biomass) in living organisms (essentially invisible free microorganisms, or visible macro-organisms and microorganisms living in them). Inputs of labile organic matter frequently tend to increase, and often double, the mineralization rate of more recalcitrant organic matter. Scientists call this phenomenon "priming effect" (Guenet et al., 2010). The decomposer living network is still partially understood and under investigation (Straatsma et al., 1994; Anastasi et al., 2005; Jayasinghe and Parkinson, 2009; Mummey et al., 2010; Burns et al., 2013; Lange et al., 2015; Ballhausen and de Boer, 2016; Geisen et al., 2016);

- During the process of respiration about $2 / 3$ of the $C$ content of organic remains is lost in the atmosphere as $\mathrm{CO}_{2}$ and $1 / 3$ incorporated in new microorganisms. If the $\mathrm{C} / \mathrm{N}$ ratio of organic remains is $\leq 30$, and if all $\mathrm{N}$ can be incorporated in new microbial structures (McDowell and Clark-McDowell, 2008), the process of biodegradation can go on fast and well until the complete utilisation of the organic remains. Microorganisms can incorporate $\mathrm{C}$ and $\mathrm{N}$ in respect to their own $\mathrm{C} / \mathrm{N}$ structural ratio, even if $2 / 3$ of the $\mathrm{C}$ of organic remains is lost to the atmosphere. If the $\mathrm{C} / \mathrm{N}$ ratio of organic remains is $>30$, the process of bio-transformation slows down and is arrested by lack of $\mathrm{N}$. However, the process can be restarted by adding available $\mathrm{N}$ for microorganisms, often in the form of ammonium sulphate (compost activator), even if unexpected reactions can occur, which are still under investigation (Fog, 1988; Pérez-Piqueres et al., 2006; Ros et al., 2006; et al., 2008; McDowell and ClarkMcDowell, 2008; Guo et al., 2012; Darby et al., 2016; Paul, 2016); 
- Fungi and bacteria do not play the same role in the decomposition process (Hole, 1981; Fitter and Garbaye, 1994; Straatsma et al., 1994; Boddy and Watkinson, 1995; Schröter et al., 2003; Castellano et al., 2015; Geisen, 2016; Khan et al., 2016). In general, the higher the C/N ratio, the higher the lignin content of the remains and the more the process is led by fungi in acid conditions; low $\mathrm{C} / \mathrm{N}$ and low lignin content are on the contrary favourable to bacteria in neutral or alkaline conditions. When making a compost, man tries to avoid acid conditions by adding material in order to maintain a $\mathrm{C} / \mathrm{N}$ ratio around 30 ;

- Examples of materials listed with increasing $\mathrm{C} / \mathrm{N}$ ratio (mean indicative values):

o Chicken manure: 7-10

o Green material (grassland, lawn, meadow cuttings): 10-30

o Tender tree leaves such as hornbeam, ash, cherry tree, elm, etc.: 10-30

0 Fruit peels such as of tomato, grape, olive, orange, etc.: 20-30

o Bovine, horse, pig manure: $20-30$

o Less tender tree leaves such as oak, plane, beech, etc.: $20-40$

o Persistent broad leaves such as holm oak, cork oak, olive tree, etc.: 30-50

o Coniferous needles such as pine, spruce, cypress, etc.: $40-80$

o Straw of wheat, barley, oat, corn, etc.: 80-100

o Wood mulch: 100-200

o Bark: 200-400;

- A pile of material with a $\mathrm{C} / \mathrm{N}<30$ is rapidly biodegraded in aerated, temperate $\left(10-30{ }^{\circ} \mathrm{C}\right)$, humid (40-70\% water, it loses drops of water when squeezed in a hand) conditions. Grinding woody material in pieces $<2 \mathrm{~cm}$ speeds up the process. Out of these optimal conditions, biodegradation slows down or is arrested (Mustin, 1987; Cambardella et al., 2003; McDowell and Clark-McDowell, 2008; Gerbier, 2015);

- Real systems are always more complicated than expected (Jones and Martin, 2003; Uzun, 2004; Jones and Saison et al., 2006; Thummes et al., 2007; Farrell and Jones, 2009; Vogel and Dussutour, 2016). However, by selecting/mixing good organic remains (absence of pollutants and good $\mathrm{C} / \mathrm{N}$ balance) and maintaining the right aeration/temperature level in the core of the pile, even a child may use the decomposing power of a techno humus system.

\subsection{Example of home-made manure humus systems}

Figures $1 \mathrm{a}$ and $\mathrm{b}$ represent very common devices used for the preparation of a manuring humus system (compost). People just drop their organic kitchen refuses in a box or form with them a pile directly on the soil (advantages of the box: it hides remains and increases temperature and moisture). A periodic control of the process of decomposition is necessary. Bad smells are produced by anaerobic decomposition, which is avoided by maintaining a right $\mathrm{C} / \mathrm{N}$ of the material and aerating/returning it from time to time. During the process of decomposition - which lasts from a few months to a year, depending from climatic conditions, composition of remains and care given to the mass under decomposition - the mound is shared in humus horizons as in natural humus systems, with a sequence of less decomposed organic remains at the top (OL), and organic-mineral horizon at the bottom (A), and a gradual passage through more or less decomposed $\mathrm{OF}$ and $\mathrm{OH}$ organic horizons. If not continuously fed, in temperate climatic conditions a well-equilibrated $(C / N=$ 
30) cumulus will finish its course by transforming all the remains in an organic-mineral biomacrostructured A horizon. The system works like a natural Mull. Note that this near-natural process can be observed only if the cumulus is in tight contact with a living soil: on a concrete basement, the compost pile must be inoculated with earthworms (vermicomposting) or, preferably, added with some amount of living soil to our disposal in a garden. For the sake of comparison pictures of humus horizons and profiles of natural humus systems are reported in articles published in Humusica 1 and 2 (refer to Humusica 1, article 4 and Humusica 2, article 13 for description and classification of specific humus horizons). If the process is arrested in earlier phases, or if the compost pile is continuously fed with fresh organic remains without being blended the cumulus shows $\mathrm{OL}, \mathrm{OF}$ and $\mathrm{OH}$ organic horizons, and the series corresponds to the horizons of a natural Amphi. In colder conditions, the process can reproduce a Moder (with a thin biomicrostructured A) or even a Mor (organic horizons over a clear abiotic organic mineral or mineral horizon) system. Wood-rich litter displays the same process of decomposition as Ligno humus systems (see Humusica 2, article 13).

To summarize, a Techno humus system (compost pile) corresponds to the biotransformation before use of an organic material prepared and mixed by man (e.g. organic residues, humus-like substances, biodegraded leaves, twigs, fruits, wood chips, straw, kitchen scraps except metal and fats or meat, Figure 2a) through decomposition (mineralisation) and maturation (humification). The pile of material tends automatically to structure itself in "horizons" as a natural humus profile (Figs. 2bd). The series of thus formed horizons depends on climatic conditions, which are more or less controlled by man. In temperate climates, the process ends with organic top layers rich in macro-, meso and micro-fauna (e.g. woodlice, millipedes, tipulid larvae, epigeic earthworms like Eisenia fetida), fungi, bacteria and organic-mineral bottom-layers actively burrowed by large anecic and endogeic earthworms. More specialized information about compost and soil biodiversity can be found in papers by Jenkins (1999), Krogh (2010), Pankhurst et al. (1997), Steel and Bert (2011). In colder conditions the process of degradation slows down and the decomposition is incomplete because of poorer pedofauna. Often the composter pile looks like an Amphi system, because litter is continuously added and transformed in $\mathrm{OF}, \mathrm{OH}$ and $\mathrm{A}$ horizons, a process with takes weeks or months of time (Fig. 2b).

The horizons of Techno humus systems can be successfully used for gardening or farming, by simply applying them above the soil of Agro humus systems with the aim to improve soil physical/chemical characteristics, increase soil organic carbon content, favour soil life and suppress plant pathogens. An example of application of mulch to a soil poor in organic matter is presented in Figs. 3a-e. A layer of $2 \mathrm{~cm}$-thick mulch, made of material prepared with a plant shredder operating on shrub branchwood (Figs. 3a-c), and distributed on a lawn growing on a calcic Cambisol (garden in Parisian region, climate: altered oceanic; air temperature: summer $19.7^{\circ} \mathrm{C}$, winter $5.4^{\circ} \mathrm{C}$; precipitation distributed all over the year: $637.4 \mathrm{~mm}$; $\mathrm{pH}=7.3$ ), becomes an $\mathrm{OH}$ horizon after one year (Fig. 3d) and is completely assimilated in a biomacrostructured A horizon two years after the application (Fig. 3e).

More complex manure humus systems are presented and investigated in the following Sections 2, 3 and 4. A dump humus system is presented in Section 5. The use of manure humus systems for facing global change is proposed in Humusica 2, articles 17, 18 and 19. 


\section{Accelerated and controlled maturation of livestock residues with composting technique}

As part of the project RiduCaReflui of the Veneto Region

(http://riducareflui.venetoagricoltura.org), composting, as applied to a wide range of crop and livestock residues, is merely a controlled and accelerated, as well as incomplete, version of the complex and slow processes of decomposition and re-composition of organic matter that occur in nature; in both cases the principal actors are bacteria, fungi and actinomycetes, the activity of which is largely influenced by the type of organic substrate and climate.

Brief treatment times, simplification and control of the process are necessary to manage the substantial amounts of residues obtained from crops and livestock at the end of the numerous production cycles, with a treatment in aim of obtaining:

- sufficiently stabilized organic matter, with a low odour impact, ready for agronomic use by virtue of its amending or fertilizing properties;

- a sanitation effect induced by the temperature rise in the mass, possibly above $60-70^{\circ} \mathrm{C}$, and maintained for sufficiently long times to kill most pathogenic microorganisms.

\subsection{The case study}

We describe two trials of on-farm composting for the treatment of by-products obtained from poultry farms. Attention to the poultry sector derives from the fact that, in Veneto, the concentration of farms in some areas creates a critical situation due to the lack of land at an economically viable distance for the agronomic use of manure. This situation was made even more critical by the high nutrient content of poultry by-products, enough to consider these by-products as potential organic fertilizers. Far from being negative, this provides the solution to the problem of their correct use, which consists of their transformation into NP organic fertilizers; a condition that can only be reached after a suitable sanitation treatment obtained by maintaining the product at a temperature of $70^{\circ} \mathrm{C}$ for at least $1 \mathrm{~h}$ (EC Regulation No 1069/2009).

These were the reasons that motivated a specific trial (as part of the project RiduCaReflui of the Veneto Region, http://riducareflui.venetoagricoltura.org), which was conducted in 2009-2011 with the aim of verifying that this activity, based on a correct operational protocol, with normally available machinery, and optimal guarantee of success given that the real work is done by microorganisms, could be implemented at farm level. Up to now this process has only been carried out in authorized production plants.

The trial treated the droppings of laying hens and the litter manure of broilers with the "controlled storage" technique, aimed at obtaining a sanitized and mature end product potentially suitable for the production of fertilizers with appropriate characteristics for sale. The idea came from the observation that, when manure remains in the manure heap, aerobic fermentation develops 
that, even if locally, leads to an increase in temperature of the piled material. This led to the conviction that these fermentations, if suitably manipulated, could contribute to sanitizing the entire mass with an effect comparable to that validated by the current EU regulation on animal by-products (EC Regulation 1069/09 and EU Commission Regulation 142/11), which suggests a treatment at a temperature of $70^{\circ} \mathrm{C}$ for at least $1 \mathrm{~h}$.

A necessary condition is to arrange the material in windrows in order to guarantee sufficient aeration and make turning possible with the machinery available on the farm (Gerbier, 2015; Guercini and Rossi, 2001; Levasseur and Aubert, 2006).

The piles were monitored by continuous recording temperature at different points and depths, with samples taken at beginning and end of the windrow treatment for the determination of physico-chemical (TS, Ntot, Norg, Psol, Corg, C/N) and microbiological parameters (Clostridium perfringens, Enterobacteriaceae, Salmonella spp.).

\subsection{Results}

The trial lasted for three years and involved 3 farms of broilers and 2 of laying hens, all with a manure heap on which to form the windrows. A total of 10 treatment cycles were monitored. The trial protocol involved the following elements:

- time of treatment of materials in the windrow

- dimensions of the windows

- carrying out of the turning(YES/NO) and number of turnings

- covering of the manure-heap (YES/NO)

Table 1 reports the characteristics of the protocols implemented during the two periods of the trial:

- Phase I, preliminary verification, with the treatment lasting 90 days and either no turning or 2-3 operations/cycle.

- Phase II, with the treatment lasting 60 days and 3-4 turnings.

The most significant result obtained in Phase I regards the temperature of the windrows, which never went above $60^{\circ} \mathrm{C}$ in static windrows and $70{ }^{\circ} \mathrm{C}$ in those turned (Figs. $4 a$ and b).

Due to the low temperatures reached the material obtained at the end of the treatment period was not suitable from the microbiological point of view.

In Phase II the modification of the trial protocol, and in particular the use of 3-4 turnings per cycle, allowed the threshold of $70^{\circ} \mathrm{C}$ to be reached and exceeded in all the windrows (Figs. 5a and b) and to obtain an end product suitable from the microbiological point of view.

\subsection{Conclusions}


The results obtained from this trial demonstrate the ability of the composting treatment to guarantee the microbiological suitability of a product, such the litter manure of broilers and droppings of laying hens, for its potential utilization as an organic fertilizer.

The turning was decisive in reaching this objective, for the following reasons:

- it guarantees an adequate supply of oxygen necessary for the aerobic fermentation, in turn responsible for the maturation and stabilization of the organic matter;

- it allows the threshold of $70^{\circ} \mathrm{C}$ to be reached and exceeded, which is necessary to guarantee the sanitation of a product;

- high temperature and repeated turning allow controlling the proliferation of troublesome insects;

- the time limit of at least $1 \mathrm{~h}$ of exothermic phase appears to be largely exceeded and guaranteed for the entire mass of the windrow, thanks to repeated turnings during the treatment period; two turnings were performed in the first 30 days, i.e. during the phase when the activity of thermophilic bacteria is more intense;

- it reduces the moisture content of the product, and thus its mass and volume, making easier management of the material (piling, transport, distribution).

Covering of the manure-heap, while not apparently having influenced the results (rainfall was modest during the trials), is any way necessary in order to guarantee adequate conditions for the process and to be able to perform the turning independently of weather conditions.

\section{How the Environment Service of Paris maintains and improves the soils of green areas with compost}

Founded in 1982 in the premises of the École du Breuil, the Laboratory of Agronomy moved in 2013 to the Parc Floral de Paris (Bois de Vincennes). Its main mission is to monitor soil quality in Parisian parks and alignment plantations and the quality of nutrient solutions and substrates used in plant production. It develops fertilization programs tailored to each culture and may eventually look for causes of plant diseases or accidents. It intervenes upstream of development projects to qualify culture substrates and monitors the supplies by ensuring compliance with the requirements of CCTP (e.g. quality of materials, nature and proportion of amendments). It participates in the implementation of the rational irrigation method MIR by quantifying available water capacity and rate of water infiltration.

Each year, the laboratory conducts physical, chemical and biological analyses on several hundred samples. To date, it manages a large database of over 20,000 urban soil samples. Over the years, the laboratory has established more efficient and automated equipment, which allowed it to increase its processing capacity and added new parameters to conventional dosages carried out routinely. Thus, to secure the use of educational or shared gardens and to support the development of urban agriculture, it performs a routine dosage of main heavy metals. In addition, to meet the 
requirements of the ecolabelling of green spaces and to help monitoring their biodiversity, biological analyses were developed, such as microbial biomass and basal respiration. In general, the activity of the laboratory is in the philosophy of sustainable soil management.

In support of studies and experiments conducted by the services of the Direction des Espaces Verts et de l'Environnement (DEVE) or in the framework of partnership agreements, the laboratory brings its expertise to develop protocols and to measure and interpret agronomic data. In this regard, it participates in studies on "sludge recycling of Haussmann gardens," "characterization of native wall floras," "greening fairways of woods and cemeteries," "experimental kitchen gardens," "contribution of private green spaces to biodiversity," "cool islands," "recycling of demolition materials," "longterm effects of straw mulching," "urban farms in île-de-France", etc. It is also engaged in calls for proposals launched by the Municipality of Paris: "Innovative revegetation," "urban metabolism," "biodiversity of Parisian green spaces", etc. Under the term project "100 ha on walls and roofs," it develops a program on the characterization of substrates and their constituents.

Through a partnership supported by the association Paris Region Lab, LaboAgro and LaboExpert two applications have recently been deployed. The former ensures computerization of requests for analyses, automation of laboratory processes and dialogue with applicants. The latter allows the interpretation of results and the edition of reports. Apart paperless results of analyses, it aims to better meet the principles of implementing environmental management in Parisian parks, certified by the Ecojardin label. In this regard, it includes the reduction of soil enrichment thresholds and/or fertilization rates, and the contribution of straw mulch from former lawns and legumes to nitrogen nutrition and nutrient supply. It also aims to participate in the training of analytical personnel through the integrated definition of scientific and technical terms (see tooltips).

\subsection{Recycling organic waste}

The DEVE service maintains 422 ha of gardens and 22 ha of flowerboxes. This generates a production of green waste (GW) estimated at $22,532 \mathrm{~m}^{3}$ per year; which is divided into $3227 \mathrm{~m}^{3}$ grass clippings, $2894 \mathrm{~m}^{3}$ trimming waste, $10,861 \mathrm{~m}^{3}$ floral decorations and $5550 \mathrm{~m}^{3}$ pruning waste. Since 2007, Parisian Christmas trees are collected in green areas to make compost or mulch used in shrubbery and driveways. Pruning homogenates from roads are also deposited in the gardens for an estimated volume of $2600 \mathrm{~m}^{3}$ in 2014 . In parallel, actions are undertaken to reduce GW such as the selection of plant species, differentiated management and reasoned irrigation. Except for health reasons (e.g. box-tree moth, horse-chestnut leaf-miner), in which case they are sent to incineration plants $\left(150 \mathrm{~m}^{3}\right.$ in 2014), the goal is to reuse a maximum of waste for mulching. This applies today to about $50 \%$ of the material collected. The remainder is recovered by composting, either in one of the 69 areas installed in the gardens $\left(300-700 \mathrm{~m}^{3} / \mathrm{yr}\right)$, or in an industrial station as part of an evacuation by skips market $\left(10,000 \mathrm{~m}^{3}\right.$ in 2014).

Whether in the form of mulch or compost, green waste is an opportunity for Parisian gardens, insofar as they offer many advantages: saving water, reducing weeds, fighting against 
slaking and erosion, stimulating biological activity, enriching the soil with organic matter, plant nutrition, etc.

\subsection{Experiments for a better use of organic matter}

Besides regular monitoring of soil fertility through analyses, the repository of the Ecojardin label recommends the practice of mulching. However, it appears that nutrient or potentially dangerous aspects are rarely invoked. To better understand it, two studies are conducted on the territory of Paris: "long-term mulching experiment" and "contribution of mulching to mineral crop nutrition."

The experimentation of main mulches used in green areas is conducted since 2004 in the Fruticetum of the École du Breuil (Figs. 6a, b). It covers 9 products and an untreated control (fresh pruning homogenate, composted pruning homogenate, tree leaves, mowing waste, Christmas tree homogenate, pine bark, cocoa shells, linseed flakes, Fibralgo) with 3 replicates each, meaning 30 parcels with an average area of $95 \mathrm{~m}^{2}$. In addition to regular field observations (plant growth, health status, development of weeds, annual breakdown thickness), laboratory analyses and in situ measurements are performed periodically. These relate to physical-chemical (organic matter, $\mathrm{pH}$, conductivity, cation exchange capacity, $\mathrm{C} / \mathrm{N}$ ), chemical (phosphorus, potassium, magnesium, calcium, sodium, heavy metals), physical (water infiltration rate) and biological (microbial biomass, microbial productivity, earthworm population size, basal respiration) parameters.

After 10 years of observations and analyses, it appears that there is no universal product use. According to their ability to provide humus and/or mineral salts, and according to their rate of degradation, each of the tested products may be of interest - limited in time - to improve or correct some behaviours of the soil. Some have similar efficacy to fertilizers. Positive action on biodiversity is not clearly demonstrated, it will require making additional observations (arthropod and earthworm activity) with a support from the Institute of Ecology and Environmental Sciences (IEES) and the National Museum of Natural History (MNHN).

\subsection{Contribution of mulching to the mineral nutrition of cultures}

Noting that mulching is a practice widely grown in Parisian gardens while its nutritional potential is often ignored, another study was launched in 2015 to understand: 1) the diversity of mulches and their degradation rate; 2 ) their nutrient content; 3 ) the concentration of undesirable elements (heavy metals). It aims primarily to enrich the LaboExpert database used in fertilizer plans and anticipate the risk of diffuse pollution.

The first part of the study was treated as a field survey of 57 supervisors responsible for supervising the 1300 gardeners of the City of Paris. This strategy of "expert opinion" was chosen to overcome the diversity of soils, crops and aspects, which would have justified increasing the number 
of field experiments. It helped to quickly obtain a comprehensive knowledge of the different types of mulch, a weighted average of the thickness implemented and annual degradation rates.

Twenty-four types of organic mulch are being used in Paris (crushed felling waste, crushed bamboo, ground material of various leaves, crushed leaves of plane tree, crushed Christmas trees, shrub trimming homogenate, tree pruning homogenate, green waste compost + horse manure, recycled wood chips, Copoflora ${ }^{\circledR}$, buckwheat husks, grass clippings, pine bark, Miscanthus leaves, cocoa shells, Fibralgo $^{\circledR}$, coconut fibre, horse manure, straw, hemp flakes, flax flakes), but also 5 mineral mulches (pozzolan, slates, bricks, gravels, porphyry) and 3 synthetic mulches (plastic sheets, biodegradable fabric, newspapers). In the spirit of the Ecojardin label, organic mulch from a local production is favoured with a clear predominance of crushed material (pruning, felling, trimming, Christmas trees) and grass clippings (Fig. 7); i.e. more than $60 \%$ of cases. Conversely, commercial mulches are less and less used. The majority of the 57 gardening workshops use 4-5 different mulches and 3 of them use up to 9-12 mulches.

The survey of 21 among these mulches showed that the thickness of the mulch was often higher than its annual degradation (Fig. 8). This causes three different management strategies: 1) charging after complete decomposition; 2) partial reload according to decomposition; 3) burying residues before reloading. In any case, the objective is to never let the ground bare. For some fast decomposing mulches (grass clippings, straw, Copoflora ${ }^{\circledR}$, cocoa shells, hemp flakes and Fibralgo ${ }^{\circledR}$ ) which require recharging during the year, it has been observed that the degradation is greater than the thickness at implementation.

The other part of the study is based on laboratory tests. Normally 3 or 4 samples of each type of mulch should be removed during the field survey, provided that their decomposition is not too advanced. According to this criterion, 44 samples were collected for the first measurement campaign. They allowed us to determine not only their concentration in $\mathrm{N}, \mathrm{P}_{2} \mathrm{O}_{5}, \mathrm{~K}_{2} \mathrm{O}$ and $\mathrm{MgO}$, but also their density, $\mathrm{pH}$ and conductivity (Table 2), organic matter and $\mathrm{C} / \mathrm{N}$. In terms of $\mathrm{pH}_{\mathrm{H} 2 \mathrm{O}}$, we observed that mulch pH ranges from an acid level (minimum 5.4) to a very basic level (maximum 10.0).

Some mulches have a high conductivity, reflecting a strong nutritional potential even before the degradation process is initiated. Like an organic fertilizer, cocoa shells have an extremely high salinity $(1516 \mu \mathrm{S} / \mathrm{cm})$.

According to the standard NF U-44-051 an organic soil is characterized by levels of $\mathrm{N}, \mathrm{P}_{2} \mathrm{O}_{5}$ and $\mathrm{K}_{2} \mathrm{O}$ less than $3 \%$ of the gross product and a sum of these elements below $7 \%$. It is noted that with the exception of grass clippings and cocoa shells, which have the same concentrations as a fertilizer, all types of mulch meet this definition.

When reported to the needs of $\mathrm{N}, \mathrm{P}, \mathrm{K}, \mathrm{Mg}$, the contribution of mulching to the mineral nutrition of different cultures (roses, summer flowers, shrubs) was simulated with a classification in 5 categories: low $(<70 \%)$, satisfactory (70-100\%), high (100-200\%), very high (200-1000\%), excessive (>1000\%). In the majority of cases, it appears that mulch caused over-fertilization (Fig. 9), and when needs were not fully satisfied, they mainly relate to phosphorus. This is not problematic in the Parisian soil which is commonly saturated with this element. When it is lacking, plant needs can be easily compensated by fertilizer inputs or simply by the reasoned use of mulch. 
The analysis of trace elements in the mulch aims at understanding the risk of transfer to soil and plants. To the extent that trees are constantly exposed to urban pollution (e.g. soil, atmospheric fallout, runoff), the mulch from crushed pruning or felling seems particularly concerned. Among the 9 trace elements (ETM) considered as indicators of pollution ( $\mathrm{Hg}, \mathrm{Pb}, \mathrm{Zn}, \mathrm{Cu}, \mathrm{Cr}, \mathrm{As}, \mathrm{Se}, \mathrm{Ni}$ and $\mathrm{Cd}$ ), mercury, arsenic and selenium were not dosed in the first phase of the study. Standards NF U-44-051 and NF U-44-095, regarding the quality of organic amendments and composts, show maximum concentrations or trace elements, as well as annual and decadal flows not to be exceeded. If all mulches meet the requirements of these standards in terms of concentrations, some of them generate excessive flows when considering their annual rate of degradation.

For zinc (Table 3), the maximum concentration (600 ppm) is never reached (10-205 ppm) but the annual (9,000 g/ha/year) and/or decennial (30,000 g/ha/year) flow is exceeded for crushed Christmas trees, compost + horse manure, Copoflora and/or Fibralgo. For cadmium (Table 3), the maximum concentration ( $3 \mathrm{ppm}$ ) is never reached $(0.02-0.92 \mathrm{ppm}$ ) but the annual flow (45 $\mathrm{g} / \mathrm{ha} /$ year) and/or decennial ( $150 \mathrm{~g} / \mathrm{ha} /$ year) is exceeded for the Christmas tree crushed, compost + horse manure, Copoflora, Fibralgo and/or flax straw.

These results suggest a risk of soil contamination from prolonged and unreasoned use of some mulch. In line with the long-term mulching experiment (Fruticetum of the École du Breuil), they confirm the interest to vary the nature of the products over the years.

\section{Composting practices and soil organic matter increase}

In Italy, the use of chemical fertilizers is undergoing a significant decrease, registering a downward trend of about 45\% in the decade 2002-2013 (ISTAT, 2015). This trend is a result of the increased cost of fertilizers, linked to fluctuations in oil prices in the international market. Ecological and socio-economical costs derived from the conventional agriculture are also elevated, especially because of the intensive and extensive use of chemical inputs that caused a decline in soil fertility. In order to change from conventional to sustainable agriculture, it is desirable to use organic amendments, cover crops, nitrogen-fixing crops and biological control (Tilman et al., 2002).

The use of organic material for fertilizing the crop arises as a relevant alternative (Bulluck et al., 2002). Among most significant properties its ability to influence soil structure and retain water should be mentioned. Organic amendment is also able to improve the structure of clay soils, reduce the susceptibility to surface erosion, alleviate compaction, as well as many features that play a role in the availability of nutrients. In addition to the above functions, a special note is deserved to the inactivation of biotoxic compounds both of natural origin (e.g. polyphenols) and synthetic origin (e.g. herbicides and pesticides) (Chenu et al., 2000; Gardner et al., 1999).

There are several substrates which can be used as a source of organic matter, varying in types and characteristics, the best known being animal manure, especially from cattle ranches. However, we can cite other sources: 
- Municipal solid waste compost (MSW) (Fig. 10a). Domestic solid waste management and treatment is one of the most common problems in cities worldwide (Chen et al., 2010; Fagnano et al., 2011). In Italy, selective collection is increasing and its efficiency can reach $65 \%$ in some regions (Ragazzi and Rada, 2008). Municipal solid waste compost obtained from processing the biodegradable fraction of municipal waste can be used in agriculture, reducing conventional landfill disposal and recycling valuable organic material. Composting is a biological process wherein occur the decomposition and transformation organic matter under controlled aerobic conditions to obtain a stable, humus-like end product (OzoresHampton et al., 1994; Montemurro et al., 2005; Farrell and Jones, 2009; Mylavarapu and Zinati, 2009; Fagnano et al., 2011) and increase soil organic matter (Mylavarapu and Zinati, 2009; Fagnano et al., 2011). According to Cala et al. (2005), the use of compost from municipal solid waste helps increasing content and stability of soil organic matter. Particularly, in Mediterranean areas the mineralization of organic matter is encouraged by the succession of dry-warm to cold-humid seasons and the continuous use of the land for horticultural purposes. Several studies demonstrated that the repeated application of municipal solid waste compost consistently increased soil organic matter content and soil $\mathrm{C} / \mathrm{N}$ ratio to levels greater than those of unamended soil (Crecchio et al., 2001; Montemurro et al., 2005). It is very important not to exceed organic amendment in amount because this substrate is rich in nutrients and an excessive use may cause pollution and inhospitable environments for plant growth.

- Anaerobic digestate residue (ADR) (Fig. 10b) is obtained from the biological process by which different organic feedstocks are converted into biogas (in the absence of oxygen) in order to produce energy or heat (Tambone et al., 2009). Mediterranean countries are responsible for about $60 \%$ of world wine production (Bustamante et al., 2007), therefore winery and distillery industries generate plentiful quantities of liquid and solid wastes. Some industries reuse winery and distillery wastes mixed with other heterogeneous organic materials as a substrate to produce biogas. The output product at the end of this process presents a low $\mathrm{C} / \mathrm{N}$ ratio and high nutrient levels, thereby it can be used as fertilizer or amendment in open field horticulture (Salminen et al., 2001).

- Spent mushroom compost (SMS) (Fig. 10c). Mushroom substrate usually consists mainly of horse manure, but different historical developments led to reduce costs significantly by adding poultry manure and straw (Maffi, 2011). Currently mushroom substrate is a mixture of horse manure, poultry manure, and straw in different percentages (Beyer, 2003). It is used for the culture of Agaricus bisporus and $5 \mathrm{~kg}$ of mushroom substrate are needed to obtain 1 $\mathrm{kg}$ of mushroom (Williams et al., 2001; Rasib et al., 2015). The farming amendment, at the end of the mushroom cultivation cycle, is an organic substrate rich in nutrients (Jordan et al., 2008), especially nitrogen, which has a considerable agronomic value when used as a fertilizer or soil improver (Curtin and Mullen, 2007; Medina et al., 2009; Zhang et al., 2012).

In order to increase the organic matter content of the soil and at the same time enhance the value of waste materials, we conducted an experiment in which the soil was fertilized with materials quoted earlier. Several vegetables have been tested and their main quantitative parameters were evaluated. Chemical characterization was also conducted in marketable yield and in the soil. 


\subsection{Compost types and characteristics}

A long-term experiment was conducted at the Experimental Station "L. Toniolo," University of Padova, northeastern Italy $\left(45^{\circ} 21^{\prime} \mathrm{N}, 11^{\circ} 58^{\prime} \mathrm{E}\right)$ (Fig. 11). In these experiments, three different substrates were tested and in some cases a positive response was obtained when using an organic substrate to fertilize the soil (Gobbi et al., 2016; Camacho Barboza et al., 2014). Comparisons were between an unfertilized control (TO), a totally mineral treatment (TMIN), a treatment called T50 in which $50 \%$ of crop nitrogen requirement was supplied by organic amendment and the remaining requirements with a mineral fertilizer, and a treatment called T100 in which $100 \%$ of nitrogen requirements of the crop were supplied by organic amendment. In two of the three organic substrates tested we introduced other treatments. In fields fertilized with compost from biodegradable municipal waste a double amount was also supplied (T200). In fertilization with anaerobic digestates, an intermediate treatment between T50 and T100 was introduced in which $75 \%$ of crop nitrogen requirements were supplied by organic amendment (T75).

Types of compost used:

- Municipal solid waste compost (MSW). The municipal solid waste compost is produced in a large local farm (S.E.S.A. S.p.a.) in the form of vegetable feedstock, like pruning waste and other plant materials. Municipal solid waste composts, when applied to different types of field crops, cause various plant responses, because each soil has its own chemical and physical peculiarities, thereby nutrients which are present in the compost may vary in their availability. The soil in which this test was conducted is an alkaline loam $(\mathrm{pH} 8)$ with a low availability of nutrients such as iron, manganese, copper, zinc and especially boron and phosphorus. Three fertilization combinations were tested using MSW-compost: the first one was fertilized with $50 \%$ of crop nitrogen requirements by MSW-compost added with $50 \%$ mineral fertilizer (T50); the second one was fertilized with 100\% of crop nitrogen requirements by MSW-compost (T100) and the last one with 200\% MSW-compost (T200). There was also one plot unfertilized (TO), and another one with mineral fertilization (TMIN) (Fig. 12a). During these years we have tested both winter crop vegetables and spring/summer crop vegetables for almost 10 years, including tomato and late radicchio. In this short communication, we will show results concerning vegetables quoted early.

- Anaerobic digestate residue (ADR). In the same way as with municipal solid waste, we used a different amount of anaerobic digestate as fertilizer in open field horticulture. In particular, we compared unfertilized control (T0), mineral fertilizer (TMIN), T50 (50\% ADR and 50\% mineral fertilizer) and T100 (100\% ADR) (Fig. 12b). The experiment started in 2005 and is continuing till now. Late cauliflower (Brassica oleracea L.) was cultivated in 2009 and late chicory (Cichorium intybus) was grown in 2010.

- Spent mushroom substrate (SMS). The same approach was used for spent mushroom substrate. SMS samples were collected from 14 mushroom growers located in the Veneto region; then the chemical characterization of samples was conducted in order to estimate the amount of fertility elements. A randomized block experimental design provided a comparison of four treatments: unfertilized control (TO); mineral control (TMIN), in which $100 \%$ of crop nitrogen requirements were supplied by mineral fertilizer; T50 in which $50 \%$ of 
crop nitrogen requirements were supplied by SMS and the remaining requirements with mineral fertilizer; T100 in which $100 \%$ of crop nitrogen requirements were supplied by SMS (Fig. 12c). During the experiment, we tested the open batavia lettuce (Lactuca sativa) and leek (Allium porrum) fertilized with different amounts of spent mushroom substrate (Gobbi et al., 2016). We have chosen one short cycle crop and one long cycle crop in order to compare different crops and estimate the efficacy of spent mushroom substrate in open field horticulture at different seasons.

\subsection{Soil sampling and data analysis}

The soil is classified as Typic Eutrudept coarse-loamy, mixed, mesic (USDA) (WRB: Haplic Cambisols (Calcaric, Hypereutric). Soil samples were collected for MSW and ADR experiments at 0-30 $\mathrm{cm}$. Samples from different points of each plot were taken and mixed, with the objective of obtaining a unique homogeneous and representative sample. Soil samples were air-dried at room temperature and passed through $2 \mathrm{~mm}$ sieve before determining soil organic carbon (SOC) by the Walkley-Black method and total nitrogen (TKN) by the Kjeldahl procedure. Also, we conducted pH analyses in accordance to Italian Standards Method III.1 (Ministerial Decree, 13/09/1999), measured electrical conductivity (Method IV.1 Ministerial Decree 13/09/1999) and measured anion and cation amounts in according to Method XIV.9 (Ministerial Decree 13/09/1999). Organic matter is easily calculable, although in an empiric way, by the following relation:

$\mathrm{OM} \%=\mathrm{OC} \% \times 1.724$

where:

OM\% is organic matter percentage;

OC\% is organic carbon percentage;

1.724 is the coefficient of Van Bemmelen which is based on the assumption that soil organic matter contains about $58 \%$ of organic carbon.

For each crop, statistical analyses were performed according to a factorial design with 3 field replicates as blocks. Data were analysed using ANOVA. In the case of a significant F-value, means were compared by Tukey's HSD test.

\subsection{Results and discussions}

The cultivation with the organic substrate as soil amendment and fertilizer seems to have generally positive effects on crop performance showing yields comparable to mineral fertilization in some cases. Short-cycle crops preferred mixed fertilization because organic substrate usually requires a long time for its mineralization. Organic fertilization is more effective for long-cycle crops. 


\subsubsection{Municipal solid waste compost (MSW)}

Total biomass and marketable yield are the response variables presented in this section. Treatments did not present significant differences for the response variables for tomato (Table 4). This suggests a high initial fertility in plots where the experiment was conducted. Mineral treatment (TMIN) produced the highest total biomass for late chicory during 2010, and high rainfall and low temperatures did not favour $\mathrm{N}$ mineralization in MSW-compost treatments. In some cases, mixed organic-chemical treatments provided a better result, such as the T50 treatment for late chicory. Similar results were obtained in two different experiments using MSW-compost as fertilizer, one in Florida with parsley (Petroselinum crispum [Mill.]) (Mylavarapu and Zinati, 2009) and the second in Nova Scotia with potatoes (Solanum tuberosum)(Mkhabela and Warman, 2005). In both cases, it was found that a combination of 50\% MSW-compost and 50\% mineral fertilizer produced the same marketable yield as 100\% inorganic fertilizer (Mylavarapu and Zinati, 2009; Mkhabela and Warman, 2005). Indeed a double amount of MSW does not seems to have a positive effect on agronomic performance, perhaps because the high amount of nutrients can inhibit plant growth.

\subsubsection{Anaerobic digestate residue (ADR)}

In some cases, there are not differences between treatments and on the other hand T100 treatment gave a similar yield to TMIN (Table 4). Treatments with ADR (T75 and T100) did not produce a total biomass as high as TMIN for late cauliflower in 2009, even if ADR treatments (T75 and T100) provided better results, only $9.6 \%$ lower than TMIN. It is possible to assess that the anaerobic digestate can be a valid substitute for chemical fertilization or, as an alternative, a valid adjuvant of chemical fertilization.

Concerning late chicory, during fall-winter 2010 the total biomass produced by T50 was not different from TMIN. In this case, the mineral component supplied the initial $\mathrm{N}$ requirements of the crop and the ADR released this element for further needs through mineralization.

This process stops when low winter temperatures arrive; and, at the same time, high precipitation during this period facilitates the availability of the mineralized organic nitrogen to the plant.

Unfortunately, the mineralization of organic matter depends on the weather, in particularly is subject to temperature and amount of rainfall.

\subsubsection{Spent mushroom compost (SMS)}

The total weight lowest value was observed in T0 while increasing values were found in other treatments. Concerning the lettuce, the highest value was found in T50, where a significant variation of over 27\% between fresh weight in T50 and T0 was observed (Gobbi et al., 2016; Zhang et al., 2012; Garcia-Gomez et al., 2002) (Table 4). 
As regard to Allium porrum significant differences were observed among fertilization treatments: T0 showed lower value whereas, in TMIN, T50 and T100 treatments were found similar values (Gobbi et al., 2016; Zhang et al., 2012; Garcia-Gomez et al., 2002) (Table 4). The high yield could be due to the double action of mineral fertilization and then element availability from SMS after its mineralization. This process was delayed by low-temperature values and frequent rainfall.

The cultivation with SMS as a soil amendment and fertilizer seemed to have generally positive effects on lettuce and leek performances showing yields comparable to mineral fertilization. Short cycle crops preferred mixed fertilization because organic substrate usually requires a long time for mineralization. Organic fertilization is more effective for long-cycle crops like leek. Furthermore using SMS for a long time could help increasing soil organic matter and recycling by-products from mushroom cultivation (Gobbi et al., 2016). Also for this matrix, it can be affirmed that spent mushroom substrate can offer comparable yield than chemical fertilizers.

\subsubsection{Soil}

Concerning the soil, it is possible to see a significant difference between treatments about MSW (Fig. 13a). The organic carbon level was moderately low at the start of the experiment (ARPAV, 2005) and the value increase steadily over time. The graph shows that the use of compost from municipal solid waste brings an increase in organic carbon percentage, the trend increasing with increasing content of MSW, even over a few years of utilization. This suggests that a great amount of time is necessary to incorporate enough organic matter into the soil. In the ADR treatment, the trend concerned only the T100 treatment and the growth was less pronounced than in MSW treatment (Fig. 13b). From 2007 to 2012 the increase was $0.14 \%$.

This experiment has started since a few years and we have analysed the soil and its main chemical-physical parameters, but as it can be found in several kinds of literature, the organic matter increase can be seen only after years of organic application. Therefore, using organic amendment for a long time could help increasing soil organic matter and allow recycling by-products.

As we mentioned before, in some cases the T100 treatment did not compare with TMIN in crop yield, but in the perspective of sustainable agriculture, would the farmer be willing to give up a portion of the harvest in order to maintain or increase soil fertility? This is a question all farmers should ask by themselves.

\section{Status of soil microbial activity of some mine waste disposals in South Africa}

Some areas of the South African landscape are dominated by mine tailings and they are synonymous with environmental contamination, erosion as well as degraded soils next to it. Various constrains and hostile characteristics i.e. lack of soil structure, extreme $\mathrm{pH}$ (low and high), low nutrient status and very low diversity and concentration of soil microbes are part of this "anthroscape". Poor vegetation cover on rehabilitation of South African mine tailings and a lack of 
biological norms and standards put question marks behind current practices and specifications. The determination of microbial activity in mine waste disposal environments allows for a more compressive understanding of the microbiological aspect present in the mine waste environment and its subsequent rehabilitation. Dehydrogenase activity (INF $\mu \mathrm{g} / \mathrm{g} / 2 \mathrm{~h}$ ) was measured on different acidic tailings (gold and coal) and alkaline (platinum and kimberlite) tailings as well on a natural undisturbed or polluted soil in the same vicinity. Baseline soil dehydrogenase activity level is dependent on specific chemical, physical and biological parameters of the different tailings materials. Subsequently, soil dehydrogenase activity covers an insight into soil health and soil ecosystem functioning within the different mine tailings. By integrating microbial parameters within standard rehabilitation practices one can improve rehabilitation success by providing a healthy and supportable ecosystem suitable for post-mining land use.

\subsection{A practical example}

In terms of microbiota, mine waste environments are considered an extreme environment based on the fact that there are certain physical and chemical limitations to microbial cellular processes. These physical and chemical limitations are typically at the end of gradients, for example low and high temperature, low and high $\mathrm{pH}$ and Eh, high salinity, high concentrations of metal trace elements and extremely low nutrient concentrations (Torsvik and $\emptyset$ vreås, 2008). Soil dehydrogenase activity (DHA) is considered one of the most important among all the enzymes in the soil

environment. DHA is considered a good indicator of the overall microbial activity in soil and relates to the total viable microorganisms within the soil environment (Taylor et al., 2002; Gu et al., 2009; Salazar et al., 2011).

Materials for this project are from gold tailings originating from three different gold mining operation localities. This includes 1) gold tailings from a gold mining operation near Stilfontein in the North-West province; 2) New Machavie gold mining operation located $\pm 21 \mathrm{~km}$ west of Potchefstroom in North-West province; 3) Dominionville situated $\pm 24 \mathrm{~km}$ from Klerksdorp in the North-West. Gold mined from these three gold mines was comprised of different gold-bearing reef deposits, i.e. Dominion Group, Witwatersrand, and Transvaal Supergroup. The gold ore of the Stilfontein mine was mined from the Klerksdorp Goldfield. This forms part of the Witwatersrand Supergroup. The Central Rand Group provided the bulk of all ore mined in the area. The Dominionville mine forms part of the Dominion Group. New Machavie is situated on the Black Reef Formation of the Transvaal Supergroup. The platinum tailings are from the Merensky and Upper Group No. 2 reefs, which forms part of the Bushveld Igneous Complex. The kimberlite tailings are from the Cullinan kimberlite pipe, which occurs within the stable, Kaapvaal Craton and intrudes rocks of the Transvaal Supergroup, Bushveld Igneous Complex and the younger Waterberg Group. Both the fine and discarded coal tailings originate from the Witbank coal seam, which is situated on the northern sector of the Karoo Supergroup (Johnson et al., 2006).

Mine tailings are mainly comprised of crushed rock, and as such they can be considered an inorganic matrix akin to soil. However, when compared, mine tailings are considered unique, not like any natural soil. The physical, chemical, mineralogical and microbiological aspects of the tailings will 
determine their impact on ecosystem functioning and stability (Ledin and Pedersen, 1996). These physical and chemical limitations are typically at the end of gradients, for example low and high temperature, low and high $\mathrm{pH}$ and Eh, high salinity, high concentrations of metal trace elements and extremely low nutrient concentrations. Tailings are characterised as having a very low cation exchange capacity, minimal microbial populations and virtually zero organic matter content. Additionally, tailings also have low concentrations of macronutrients necessary for plant growth, in particular nitrogen $(\mathrm{N})$. On the other hand, tailings tend to have high concentrations of metal trace elements, that is particularly problematic in acidic tailings (Van Deventer et al., 2006). Furthermore, these acidic conditions greatly reduce microbial communities and soil fertility (Seaker and Sopper, 1988). In low pH conditions, acid mine drainage (AMD) is the most frequent environmental problem (Fig. 14a). Due to particle size distribution and grading properties, mine tailings are particularly susceptible to erosion and compaction resulting in the formation of huge donga-like erosion structures (Fig. 14b).

\subsection{Dehydrogenase activities in natural soils and tailings materials}

When comparing the dehydrogenase activity of natural soils to tailings materials (Fig. 14c), natural soils tend to have a higher microbial activity. The degree of which the microbial activity varies within natural soils and tailings materials provides insight into soil quality and health (i.e. degree of degradation). Like most natural soils, the ochric A horizon $(115 \mu \mathrm{g} / \mathrm{g} / 2 \mathrm{~h})$ has a much higher microbial activity compared to that of the other tailings materials. The Kalahari aeolian sand (ochric $A$ horizon) natural chemical properties (i.e. poor nutrient status and no organic matter) and physical properties (high sand \%) contributed towards the low microbial activity. B horizon soil samples include granite saprolite and Ottosdal kaolinite clay. These B horizons have a lower microbial activity (DHA) compared to those of the A horizon. This is in general agreement with earlier studies concerning soil depth and microbial activity (Blume et al., 2002; Fierer et al., 2003). In general, factors such as $\mathrm{pH}$, nutrient status, soil organic matter (SOM) tend to change with depth (Aon and Colaneri, 2001; Taylor et al., 2002; Eilers et al., 2012; Rumple and Kögel-Knabner, 2011). Along this gradient microbial biomass also tend to decline (Blume et al., 2002; Fierer et al., 2003; Šantrůčková et al., 2010), in addition a shift in the microbial community composition occurs (Eilers et al., 2012; Ekelund et al., 2001; Hartmann et al., 2009). The lower microbial activity of exposed argic B horizons indicates a degree of degradation that the horizon underwent subsequently to its exposure. Comparatively all tailings materials, not exclusive of gold tailings, have a low microbial activity with the exception of coal fines and coal discard. Noticeably, both coal discard and coal fines (Fig. 14c) have a higher microbial activity when compared to other tailings materials. The low dehydrogenase activity within the different tailings materials demonstrates the degree of soil ecological stress associated with anthropogenic soils.

While global knowledge on soil microbial diversity and functioning is quickly rising, knowledge of microbes in the rehabilitation of South African mine waste environments is scant. Microorganisms mediate important ecosystem functions in the soil and thus the recovery of the soil microbial community is a critical step in achieving the goal of sustainable and beneficial tailings restoration. In order to get a comprehensive understanding of mine waste disposal environments 
and its rehabilitation microbial processes need to be included in hypotheses, models, and interpretation of findings.

A complete description of the case briefly reported in this paper, with photographs, soil analysis, biological investigations and rehabilitation indications, is available in Humusica 3 (Schimmer and Van Deventer).

\section{Authors' contributions}

Coordinator: A. Zanella

Section 1: A. Zanella, J.F. Ponge

Section 2: S. Guercini, C. Rumor

Section 3: F. Nold, J.F. Ponge, A. Zanella, C. Chaabane, M.L. Mouchard, E. Garcia

Section 4: P. Sambo, V. Gobbi

Section 5: C. Schimmer, P.W. Van Deventer

Background music while reading? L'Herbe Folle - Marutka.

https://www.youtube.com/watch?v=KJrZjfiKZmc.

\section{References}

Adani, F., Tambone, F., Genevini, P., 2009. Effect of compost application rate on carbon degradation and retention in soils. Waste Manag. 29, 174-179.

Anastasi, A., Varese, G.C., Marchisio, V.F., 2005. Isolation and identification of fungal communities in compost and vermicompost. Mycologia 97, 33-44.

Annabi, M., Le Bissonnais, Y., Francou, C., Le Villio-Poitrenaud, M., Houot, S., 2005. Utilisation de composts pour améliorer la stabilité structurale des sols limoneux. Echo-MO 56, 3-8.

Aon, M.A., Colaneri, A.C., 2001. Temporal and spatial evolution of enzymatic activities and physicochemical properties in an agricultural soil. Appl. Soil Ecol. 18, 255-270.

ARPAV, 2005. http://www.arpa.veneto.it/temi-ambientali/suolo/file-e-allegati/cartadei-suoli-delveneto/Carta\%20dei\%20suoli\%20del\%20Veneto\%20-\%20Catalogo\%20dei\%20suoli.pdf/view. 
Ballhausen, M.B., De Boer, W., 2016. The sapro-rhizosphere: carbon flow from saprotrophic fungi into fungus-feeding bacteria. Soil Biol. Biochem. 102, 14-17.

Beyer, David M., 2003. Basic Procedures for Agaricus Mushroom. Pennsylvania State University, State College.

Blume, E., Bischoff, M., Reichert, J., Moorman, T., Konopka, A., Turco, R.F., 2002. Surface and subsurface microbial biomass, community structure and metabolic activity as a function of soil depth and season. Applied Soil Ecology 20, 171-181.

Boddy, L., Watkinson, S.C., 1995. Wood decomposition, higher fungi, and their role in nutrient redistribution. Can. J. Bot. 73, 1377-1383.

Bollen, G.J., Volker, D., Wijnen, A.P., 1989. Inactivation of soil-borne plant pathogens during smallscale composting of crop residues. Neth. J. Plant Pathol. 95, 19-30.

Brown, S., Cotton, M., 2011. Changes in soil properties and carbon content following compost application: results of on-farm sampling. Compost Sci. Util. 19, 87-96.

Bulluck III, R., Brosius, M., Evanylo, G., Ristaino, J., 2002. Organic and synthetic fertility amendment influence soil microbial physical and chemical properties on organic and conventional farms. Appl. Soil Ecol. 19, 147-160.

Burns, R.G., DeForest, J.L., Marxsen, J., Sinsabaugh, R.L., Stromberger, M.E., Wallenstein, M.D., Weintraub, M.N., Zoppini, A., 2013. Soil enzymes in a changing environment: current knowledge and future directions. Soil Biol. Biochem. 58, 216-234.

Bustamante, M.A., Pérez-Murcia, M.D., Paredes, C., Moral, R., Pérez-Espinosa, A., Moreno-Caselles, J., 2007. Short-term carbon and nitrogen mineralisation in soil amended with winery and distillery organic wastes. Bioresour. Technol. 98, 3269-3277.

Cala, V., Cases, M.A., Walter, I., 2005. Biomass production and heavy metal content of Rosmarinus officinalis grown on organic waste-amended soil. J. Arid Environ. 62, 401-412.

Camacho Barboza, J., Zanin, G., Ponchia, G., Sambo, P., 2014. Use of anaerobic digested residues in open field horticulture in the Veneto Region, Italy. Acta Hortic. 1018, 133-138.

Cambardella, C.A., Richard, T.L., Russell, A., 2003. Compost mineralization in soil as a function of composting process conditions. Eur. J. Soil Biol. 117-127.

Castellano, M.J., Mueller, K.E., Olk, D.C., Sawyer, J.E., Six, J., 2015. Integrating plant litter quality, soil organic matter stabilization, and the carbon saturation concept. Glob. Change Biol. 21, 32003209.

Chen, X., Geng, Y., Fujita, T., 2010. An overview of municipal solid waste management in China. Waste Manag. 30, 716-724.

Chenu, C., Le Bissonnais, Y., Arrouays, D., 2000. Organic matter influence on clay wettability and soil aggregate stability. Soil Sci. Soc. Am. J. 64, 1479-1486. 
Cleveland, C.C., Liptzin, D., 2007. C:N:P stoichiometry in soil: is there a "Redfield ratio" for the microbial biomass? Biogeochemistry 85, 235-252.

Crecchio, C., Curci, M., Mininni, R., Ricciuti, P., Ruggiero, P., 2001. Short-term effects of municipal solid waste compost amendments on soil carbon and nitrogen content, some enzyme activities and genetic diversity. Biol. Fertil. Soils 34, 311-318.

Culot, M., Lebeau, S., 1999. Le compostage, une pratique méconnue de gestion des déchets. Bull. d'Information AIGx 5, 11-17.

Curtin, J.S., Mullen, G.J., 2007. Physical properties of some intensively cultivated soils of Ireland amended with spent mushroom compost. Land Degrad. Dev. 368, 355-368.

Darby, I., Xu, C.Y., Wallace, H.M., Joseph, S., Pace, B., Bai, S.H., 2016. Short-term dynamics of carbon and nitrogen using compost, compost-biochar mixture and organomineral biochar. Environ. Sci. Pollut. Res. 23, 11267-11278.

de Bertoldi, M., Vallini, G., Pera, A., 1983. The biology of composting: a review. Waste Manag. Res. 1, 157-176.

Eilers, K.G., Debenport, S., Anderson, S., Fierer, N., 2012. Digging deeper to find unique microbial communities: the strong effect of depth on the structure of bacterial and archaeal communities in soil. Soil Biol. Biochem. 50, 58-65.

Ekelund, F., Rønn, R., Christensen, S., 2001. Distribution with depth of protozoa, bacteria and fungi in soil profiles from three Danish forest sites. Soil Biol. Biochem. 33, 475-481.

Evanylo, G., Sherony, C., Spargo, J., Starner, D., Brosius, M., Haering, K., 2008. Soil and water environmental effects of fertilizer-, manure-, and compost-based fertility practices in an organic vegetable cropping system. Agric. Ecosyst. Environ. 127, 50-58.

Fagnano, M., Adamo, P., Zampella, M., Fiorentino, N., 2011. Environmental and agronomic impact of fertilization with composted organic fraction from municipal solid waste: a case study in the region of Naples, Italy. Agric. Ecosyst. Environ. 141, 100-107.

Farrell, M., Jones, D.L., 2009. Critical evaluation of municipal solid waste composting and potential compost markets. Bioresourc. Technol. 100, 4301-4310.

Fierer, N., Allen, A.S., Schimel, J.P., Holden, P.A., 2003. Controls on microbial $\mathrm{CO}_{2}$ production: a comparison of surface and subsurface soil horizons. Glob. Change Biol. 9, 1322-1332.

Fitter, A.H., Garbaye, J., 1994. Interactions between mycorrhizal fungi and other soil organisms. Plant Soil 159, 123-132.

Fog, K., 1988. The effect of added nitrogen on the rate of decomposition of organic matter. Biol. Rev. $63,433-462$.

Fontaine, S., Mariotti, A., Abbadie, L., 2003. The priming effect of organic matter: a question of microbial competition? Soil Biol. Biochem. 35, 837-843. 
Garcia-Gomez, A., Bernal, M.P., Roig, A., 2002. Growth of ornamental plants in two composts prepared from agroindustrial wastes. Bioresour. Technol. 83, 81-87.

Gardner, C.M.K., Laryea, K.B., Unger, P.W., 1999. Soil Physical Constraints to Plant Growth and Crop Production. Food and Agriculture Organization of the United Nations, Land and Water Development Division, Rome.

Geisen, S., 2016. The bacterial-fungal energy channel concept challenged by enormous functional versatility of soil protists. Soil Biol. Biochem. 102, 22-25.

Geisen, S., Koller, R., Hünninghaus, M., Dumack, K., Urich, T., Bonkowski, M., 2016. The soil food web revisited: diverse and widespread mycophagous soil protists. Soil Biol. Biochem. 94, 10-18.

Gerbier, L., 2015. Charte de Bonnes Pratiques de Compostage Agricole. Agriculteurs Composteurs de France, Paris.

http://www.composteursdefrance.com/ressources/pdf/charte bonnes pratiques composta ge.pdfhttp://www.composteursdefrance.com/ressources/pdf/charte bonnes pratiques co mpostage.pdf.

Gobbi, V., Bonato, S., Nicoletto, C., Zanin, G., 2016. Spent mushroom substrate as organic fertilizer: vegetable organic trials. Acta Horticult. 1146, 49-56.

Gu, Y., Wag, P., Kong, C., 2009. Urease, invertase, dehydrogenase and polyphenoloxidase activities in paddy soils influenced by allelophatic rice variety. Eur. J. Soil Biol. 45, 436-441.

Guenet, B., Danger, M., Abbadie, L., Lacroix, G., 2010. Priming effect: bridging the gap between terrestrial and aquatic ecology. Ecology 91, 2850-2861.

Guercini, S., Rossi, L., 2001. Produzione e Impiego di Compost nell'Azienda Agricola: Manuale Pratico. Veneto Agricoltura, Venice.

Guo, R., Li, G., Jiang, T., Schuchardt, F., Chen, T., Zhao, Y., Shen, Y., 2012. Effect of aeration rate, C/N ratio and moisture content on the stability and maturity of compost. Bioresour. Technol. 112, 171-178.

Hartmann, M., Lee, S., Hallam, S.J., Mohn, W.W., 2009. Bacterial, archaeal and eukaryal community structures throughout soil horizons of harvested and naturally disturbed forest stands.

Environ. Microbiol. 11, 3045-3062.

Hatzilazarou, S.P., Charizopoulos, E., Papadopoulou-Mourkidou, E., Economou, A.S., 2005.

Persistence of chlorpyrifos, diazinon and dimethoate sprayed in the greenhouse environment during hydroponic cultivation of Gerbera. Agron. Sustain. Dev. 25, 193-199.

Hole, F.D., 1981. Effects of animals on soil. Geoderma 25, 75-112.

Huhta, V., Ikonen, E., Vilkamaa, P., 1979. Succession of invertebrate populations in artificial soil made of sewage sludge and crushed bark. Ann. Zool. Fennici 16, 223-270.

ISTAT, 2015. La Distribuzione per Uso Agricolo dei Fertilizzantie e dei Fitosanitari. Istituto Nazionale di Statistica, Rome. https://www.istat.it/it/files/2015/01/Fitosanitari-e- 
fertilizzanti.pdf?title=Distribuzione+di+fertilizzanti+e+fitosanitari+-+20\%2Fgen\%2F2015++ Testo+integrale.pdf.

Jayasinghe, B.A.T.D., Parkinson, D., 2009. Earthworms as the vectors of actinomycetes antagonistic to litter decomposer fungi. Appl. Soil Ecol. 43, 1-10.

Jenkins, J., 1999. The Humanure Handbook: a Guide to Composting Human Manure. Joseph Jenkins, Grove City.

Johnson, M.R., Anhaeuser, C.R., Thomas, R.J., 2006. The Geology of South Africa. Geological Society of South Africa, Pretoria.

Jones, P., Martin, M., 2003. A Review of the Literature on the Occurrence and Survival of Pathogens of Animals and Humans in Green Compost. Waste and Resources Action Programme, Banbury.

Jordan, S.N., Mullen, G.J., Murphy, M.C., 2008. Composition variability of spent mushroom compost in Ireland. Bioresour. Technol. 99, 411-418.

Khan, K.S., Mack, R., Castillo, X., Kaiser, M., Joergensen, R.G., 2016. Microbial biomass, fungal and bacterial residues, and their relationships to the soil organic matter $\mathrm{C} / \mathrm{N} / \mathrm{P} / \mathrm{S}$ ratios. Geoderma 271, 115-123.

Körner, I., Braukmeier, J., Herrenklage, J., Leikam, K., Ritzkowski, M., Schlegelmilch, M., Stegmann, R., 2003. Investigation and optimization of composting processes: test systems and practical examples. Waste Manag. 23, 17-26.

Krogh, P.H. (contributor), 2010. European Atlas of Soil Biodiversity. Publications Office of the European Union, Luxembourg. http://dx.doi.org/10.2788/94222.

Kuzyakov, Y., Blagodatskaya, E., 2015. Microbial hotspots and hot moments in soil: concept and review. Soil Biol. Biochem. 83, 184-199.

Lange, M., Eisenhauer, N., Sierra, C.A., Bessler, H., Engels, C., Griffiths, R.I., Mellado-Vázquez, P.G., Malik, A.A., Roy, J., Scheu, S., Steinbeiss, S., Thomson, B.C., Trumbore, S.E., Gleixner, G., 2015. Plant diversity increases soil microbial activity and soil carbon storage. Nature Commun. 6, 6707.

Ledin, M., Pedersen, K., 1996. The environmental impact of mine wastes: roles of microorganisms and their significance in treatment of mine wastes. Earth Sci. Rev. 41, 67-108.

Levasseur, P., Aubert, C., 2006. Contexte, atouts et faiblesses des effluents porcins et avicoles destinés à être exportés. Techni Porc 29(2), 3-11.

Lowenfels, J., 2014. Teaming with Nutrients: the Organic Gardener's Guide to Optimizing Plant Nutrition. Timber Press, Portland.

Lowenfels, J., 2017. Teaming with Fungi: the Organic Grower's Guide to Mycorrhizae. Timber Press, Portland. 
Lowenfels, J., Lewis, W., 2010. Teaming with Microbes: the Organic Gardener's Guide to the Soil Food Web. Timber Press, Portland.

Maffi, G., 2011. L'Italia delle Fungaie. Associazione Italiana Fungicoltori, Verona.

McDowell, C.F., Clark-McDowell, T., 2008. Home Composting Made Easy, $5^{\text {th }}$ ed. Cortesia Press, Eugene.

Medina, E., Paredes, C., Pérez-Murcia, M.D., Bustamante, M.A., Moral, R., 2009. Spent mushroom substrates as component of growing media for germination and growth of horticultural plants. Bioresour. Technol. 100, 4227-4232.

Mkhabela, M.S., Warman, P.R., 2005. The influence of municipal solid waste compost on yield, soil phosphorus availability and uptake by two vegetable crops grown in a Pugwash sandy loam soil in Nova Scotia. Agric. Ecosyst. Environ. 106, 57-67.

Montemurro, F., Convertini, G., Ferri, D., Maiorana, M., 2005. MSW compost application on tomato crops in Mediterranean conditions: effects on agronomic performance and nitrogen utilization. Compost Sci. Util. 13, 234-242.

Mummey, D.L., Clarke, J.T., Cole, C.A., O’Connor, B.G., Gannon, J.E., Ramsey, P.W., 2010. Spatial analysis reveals differences in soil microbial community interactions between adjacent coniferous forest and clearcut ecosystems. Soil Biol. Biochem. 42, 1138-1147.

Mustin, M., 1987. Le Compost: Gestion de la Matière Organique. François Dubusc, Paris.

Mylavarapu, R.S., Zinati, G.M., 2009. Improvement of soil properties using compost for optimum parsley production in sandy soils. Sci. Hortic. 120, 426-430.

Ouédraogo, E., Mando, A., Zombré, N.P., 2001. Use of compost to improve soil properties and crop productivity under low input agricultural system in West Africa. Agric. Ecosyst. Environ. 84, 259-266.

Ozores-Hampton, M., Schaffer, B., Bryan, H.H., Hanlon, E.A., 1994. Nutrient concentrations, growth, and yield of tomato and squash in municipal solid-waste-amended soil. Hort. Sci. 29, 785788.

Pankhurst, C.E., Doube, B.M., Gupta, V.V.S., 1997. Biological Indicators of Soil Health. CABI Publishing, Oxon.

Paul, E.A., 2016. The nature and dynamics of soil organic matter: plant inputs, microbial transformations, and organic matter stabilization. Soil Biol. Biochem. 98, 109-126.

Pérez-Piqueres, A., Edel-Hermann, V., Alabouvette, C., Steinberg, C., 2006. Response of soil microbial communities to compost amendments. Soil Biol. Biochem. 38, 460-470.

Ragazzi, M., Rada, E.C., 2008. Effects of recent strategies of selective collection on the design of municipal solid waste treatment plants in Italy. WIT Trans. Ecol. Environ. 109, 613-620. 
Rasib, N.A.A., Zakaria, Z., Tompang, M.F., Rahman, R.A., Othman, H., 2015. Characterization of biochemical composition for different types of spent mushroom substrate in Malaysia. Malaysian J. Anal. Sci. 19, 41-45.

Rech, H.M., 2013. Hydroponic. Food Production: a Definitive Guidebook for the Advanced Home Gardener and the Commercial Hydroponic Grower, $7^{\text {th }}$ ed. CRC Press, Boca Raton.

Ros, M., Klammer, S., Knapp, B., Aichberger, K., Insam, H., 2006. Long-term effects of compost amendment of soil on functional and structural diversity and microbial activity. Soil Use Manag. 22, 209-218.

Rumple, C., Kögel-Knabner, I., 2011. Deep soil organic matter: a key but poorly understood component of terrestrial C cycle. Plant Soil 338, 143-158.

Saison, C., Degrange, V., Oliver, R., Millard, P., Commeaux, C., Montange, D., Le Roux, X., 2006. Alteration and resilience of the soil microbial community following compost amendment: effects of compost level and compost-borne microbial community. Environ. Microbiol. 8, 247-257.

Salazar, S., Sanchez, L., Alvarez, J., Valverde, A., Galindo, P., Igual, J., Peix, A., Santa-Regina, I., 2011. Correlation among soil enzyme activities under different forest system management practices. Ecol. Eng. 37, 123-1131.

Salminen, E., Rintala, J., Härkönen, J., Kuitunen, M., Högmander, H., Oikari, A., 2001. Anaerobically digested poultry slaughterhouse wastes as fertiliser in agriculture. Bioresour. Technol. 78, 81-88.

Šantrůčková, H., Kastovska, E., Kozlov, D., Kurbatova, J., Liveckova, M., Shibistova, O., Tatarinov, F., Lloyd, J., 2010. Vertical and horizontal variation of carbon pools and fluxes in soil profile of wet southern taiga in European Russia. Boreal Environ. Res. 15, 357-369.

Seaker, E.M., Sopper, W.E., 1988. Municipal sludge for mine spoil reclamation: effects on microbial populations and activity. J. Environ. Qual. 17, 591-597.

Schröter, D., Wolters, V., De Ruiter, P.C., 2003. C and N mineralisation in the decomposer food webs of a European forest transect. Oikos 102, 294-308.

Schumacher, M., Christl, I., Vogt, R.D., Barmettler, K., Jacobsen, C., Kretzschmar, R., 2006. Chemical composition of aquatic dissolved organic matter in five boreal forest catchments sampled in spring and fall seasons. Biogeochemistry 80, 263-275.

Sommer, S.G., Dahl, P., 1999. Nutrient and carbon balance during the composting of deep litter. J. Agric. Eng. Res. 74, 145-153.

Steel, H., Bert, W., 2011. Biodiversity of compost mesofauna and its potential as an indicator of the composting process status. Dyn. Soil Dyn. Plant 5(Special Issue 2)., 45-50.

Straatsma, G., Samson, R.A., Olijnsma, T.W., Op den Camp, H.J.M., Gerrits, J.P.G., Van Griensven, L.J.L.D., 1994. Ecology of thermophilic fungi in mushroom compost, with emphasis on 
Scytalidium thermophilum and growth stimulation of Agaricus bisporus mycelium. Appl. Environ. Microbiol. 60, 454-458.

Tambone, F., Genevini, P., D'Imporzano, G., Adani, F., 2009. Assessing amendment properties of digestate by studying the organic matter composition and the degree of biological stability during the anaerobic digestion of the organic fraction of MSW. Bioresour. Technol. 100, 3140-3142.

Taylor, J.P., Wilson, B., Mills, M.S., Burns, R.G., 2002. Comparison of microbial numbers and enzymatic activities in surface soils and subsoils using various techniques. Soil Biol. Biochem. 34, 387-401.

Thummes, K., Schäfer, J., Kämpfer, P., Jäckel, U., 2007. Thermophilic methanogenic archaea in compost material: occurrence, persistence and possible mechanisms for their distribution to other environments. Syst. Appl. Microbiol. 30, 634-643.

Tilman, D., Cassman, K.G., Matson, P.A., Naylor, R., Polasky, S., 2002. Agriculture sustainability and intensive production practices. Nature $418,671-677$.

Tiquia, S.M., 2005. Microbiological parameters as indicators of compost maturity. J. Appl. Microbiol. $99,816-828$.

Torsvik, L., Øvreås, V., 2008. Microbial diversity, life strategies, and microbial adaption to life in extreme soils. In: Dion, P., Nautiyal, C.S. (Eds.), Microbiology of Extreme Soils. Springer, Berlin, pp. 15-43.

Tuomela, M., Vikman, M., Hatakka, A., Itävaara, M., 2000. Biodegradation of lignin in a compost environment: a review. Bioresour. Technol. 72, 169-183.

Uzun, I., 2004. Use of spent mushroom compost in sustainable fruit production. J. Fruit Ornam. Plant Res. 12, 157-165.

Van Deventer, P.W., Bloem, A.A., Hatting, J.M., 2006. Pedogenesis in mine tailings. In: Fourie, A., Tibbett, M. (Eds.), Mine Closure 2006. University of Western Australia, Perth, pp. 383-390.

Vogel, D., Dussutour, A., 2016. Direct transfer of learned behaviour via cell fusion in non-neural organisms. Proc. R. Soc. London B 283, 1845.

Williams, B.C., McMullan, J.T., McCahey, S., 2001. An initial assessment of spent mushroom compost as a potential energy feedstock. Bioresour. Technol. 79, 227-230.

Zhang, R.H., Duan, Z.Q., Li, Z.G., 2012. Use of spent mushroom substrate as growing media for tomato and cucumber seedlings. Pedosphere 22, 333-342.

Zhao, H.Y., Li, J., Liu, J.J., Lü, Y.C., Wang, X.F., Cui, Z.J., 2013. Microbial community dynamics during biogas slurry and cow manure compost. J. Integr. Agric. 12, 1087-1097. 


\section{Figure captions}

Fig. 1. a) Common plastic bin for home-made compost; b) Organized system for home-made compost: on the left, an iron net containing leaves collected all around in the garden; on the right a smaller opened woody box that contents small branches of bushes or trees, manually or mechanically reduced in pieces; between them, a mean sized woody box that collects home organic wastes. By adding leaves ( $C / N 20-40)$ and/or branches $(C / N>100)$ to the wastes $(C / N<20)$ it is possible to regulate the rate of the process of decomposition of the remains. With the permission of Dr. P. Darfeuille. Photographs: A. Zanella.

Fig. 2. a) Leaf litter is progressively added at the top of the organic matter set in the composter for enriching in dry matter the organic remains coming from the kitchen; b) The pile of litter tends to organize itself in soil horizons. Example in an early stage of decomposition; c) In a temperate climate, the mound of litter tends to become a Mull system, the OL horizon being transformed in a biomacrostructured A horizon by earthworms; d) Example of an $\mathrm{OH}$ organic horizon in a Techno humus system made of dried peat remains arrested at an earlier phase of decomposition. Photographs: A. Zanella.

Fig. 3. Gardening with mulch: a) Home-use common plant shredder (motor power $2000 \mathrm{~W}$; cutting capacity diameter of branches: $4 \mathrm{~cm}$; material throughput, about: $80 \mathrm{~kg} / \mathrm{h}$ ); b) Fresh mulch, branches of broad leaved bushes transversally cut in pieces less than $2 \mathrm{~cm}$ long, also longitudinally broken by the machine in the sense of the fibers, which facilitate fungal attack and decomposition; c) Mulch two months (September and October) after its distribution on a garden lawn; d) The topsoil one year after application of a layer of mulch (thickness $2 \mathrm{~cm}$ ) on a lawn; e) Two years after application all mulch is incorporated in the soil by earthworms. The structure of the mineral soil is now less compact and the soil more biologically functional and rich in organic matter. Photographs: A. Zanella.

Fig. 4. Phase I treatment of (a) layer hen manure and (b) broiler litter manure.

Fig. 5. Phase II treatment of (a) layer hen manure and (b) broiler litter manure.

Fig. 6. Characterization of main mulches used in the Fruticetum of the Ecole du Breuil (Paris): a) Organic matter (about 4\%), b) Microbial biomasse (mean values in years 2012 and 2014, C $\%$ ).

Fig. 7. Organic mulch from a local production used in green spaces of Paris. For example, mashes from branch pruning, tree slaughter or bush cutting are used in 86,90 and $98 \%$ of the city parks, respectively.

Fig. 8. Thickness of the mulch and annual degradation of 21 types of mulches. Recycled wood chips, buckwheat hulls, pine bark and Miscanthus leaves are among the most resistant to biodegradation.

Fig. 9. Simulation of mulch mineral nutrition reported to the mean needs of $N, P, K, M g$ of summer flowers and of shrubs. Many mulches add a surplus (orange or red colour) of nitrogen (first column) to summer flowers and bushes as well. A lack of phosphorus (blue colour) is evident in the case of summer flowers (second column). 
Fig. 10. Substrates used in our research as organic fertilizers: a) Municipal soil waste compost (MSW). It looks like peat or potting soil; b) Anaerobic digestate residues (ADR); c) Spent mushroom substrate (SMS). Photographs: V. Gobbi.

Fig. 11. The place where all fields fertilized with MSW (municipal solid waste), ADR (anaerobic digestate residue) and SMS (spent mushroom substrate) are located.

Fig. 12. Sampling plan: a) The randomized blocks experimental design used in the field fertilized with MSW; b) The randomized blocks experimental design used in the field fertilized with ADR; c) The randomized blocks experimental design used in the field fertilized with SMS. The different colours indicate different SMS types (SP is made of straw and poultry manure; HP is made of horse manure and poultry manure; SHP is made of straw, horse manure and poultry manure).

Fig. 13. The increase of organic carbon percentage in the soil fertilized with MSW. Treatments containing MSW show a more marked growth compared with the other treatments.

Fig. 14. New Machavie gold mine site. a) AMD "river" at New Machavie gold mine site; b) right-above severe donga-like structures due to physical properties of tailings materials; c) soil dehydrogenase activity: comparison of different tailings materials with natural soils with some of the constraints. Photographs: C. Schimmer. 
Table 1

Characteristics of the protocols implemented in the treatment of the windrows during the two phases of the trial.

\begin{tabular}{lllc}
\hline Parameters & UM & Phase I & Phase II \\
\hline duration of treatment & (d) & 90 & 60 \\
Pile dimensions & (m) & W: 3,5-4,0- H: $2,0-2,5$ \\
Turnings & $\left(\mathrm{n}^{\circ}\right)$ & 0 or $2-3$ & 3 or 4 \\
Cover & & Y/N & \\
\hline
\end{tabular}




\section{Table 2}

pHwater and conductivity of mulches. 3 or 4 samples of each type of mulch were removed during fields surveys, providing that their decomposition was not too advanced. $\mathrm{pH}$ range of three groups of mulches. Woody material is as acid than grass cutting. Mashed plane tree leaves are as basic than horse manure. Conductivity of three groups of mulches. This parameter is proportional to the nutritional potential of the mulches and shows that horse manure and grass cutting are very rich fertilizers.

\begin{tabular}{|c|c|c|}
\hline \multicolumn{3}{|l|}{$\mathrm{pH}$} \\
\hline Acidic $(<5.4)$ & Neutral (5.5-7.4) & Basic $(>7.5)$ \\
\hline Crushed Lime prunings & Crushed tree fellings & Crushed plane leaves \\
\hline Crushed Chrismas trees & Crushed bamboo & $\begin{array}{l}\text { Compost }+ \text { Horse } \\
\text { manure }\end{array}$ \\
\hline Crushed Shrub & Various crushed leaves & Copoflora $`$ \\
\hline Various crushed prunings & $\begin{array}{l}\text { Crushed Sophora } \\
\text { prunings }\end{array}$ & Buckwheat husks \\
\hline Pin bark & Recycled wood chips & Fibralgo@ \\
\hline Mowing grass & Miscanthus leaves & Horse manure \\
\hline \multirow[t]{5}{*}{ Cocoa shells } & Coconut fibre & \\
\hline & Grass straw & \\
\hline & Barley straw & \\
\hline & Hempe flakes & \\
\hline & Flax flakes & \\
\hline \multicolumn{3}{|l|}{ Conductivity $(\mu \mathrm{S} . \mathrm{cm})$} \\
\hline Low & Moderate & High \\
\hline$<100$ & $100-400$ & $>400$ \\
\hline Crushed tree fellings & $\begin{array}{l}\text { Various crushed } \\
\text { prunings }\end{array}$ & $\begin{array}{l}\text { Compost }+ \text { Horse } \\
\text { manure }\end{array}$ \\
\hline Crushed bamboo & Copoflora $\Subset$ & Cocoa shells \\
\hline Various crushed leaves & Buckwheat husks & Mowing grass \\
\hline Crushed plane leaves & Fibralgo@ & \\
\hline Crushed Chrismas trees & Horse manure & \\
\hline Crushed Shrub & Hempe flakes & \\
\hline \multicolumn{3}{|l|}{ Crushed Sophora prunings } \\
\hline \multicolumn{3}{|l|}{ Crushed Lime prunings } \\
\hline \multicolumn{3}{|l|}{ Recycled wood chips } \\
\hline \multicolumn{3}{|l|}{ Pin bark } \\
\hline \multicolumn{3}{|l|}{ Miscanthus leaves } \\
\hline \multicolumn{3}{|l|}{ Coconut fibre } \\
\hline \multicolumn{3}{|l|}{ Barley straw } \\
\hline \multicolumn{3}{|l|}{ Hempe flakes } \\
\hline Flax flakes & & \\
\hline
\end{tabular}


Table 3

Concentration of urban pollution in mulches. Example of lecture: for cadmium, the maximum concentration ( $3 \mathrm{ppm})$ is never reached $(0.02-0.92 \mathrm{ppm})$ but the annual flow ( $45 \mathrm{~g} / \mathrm{ha} / \mathrm{year})$ and/or decennial (150 g/ha/year) is exceeded (bold values) for the Christmas tree crushed, compost + horse manure, Copoflora, Fibralgo and/or flax straw. LoQ $=$ Limit of Quantification (measures of concentration under this limit are not consistent); we underlined the values higher than the limit. Zinc (Zn) annual and/or decennial concentrations exceed (bold values) for crushed Christmas trees, compost, horse manure, Copoflora and/or Fibralgo; Cadmium (Cd) annual and/or decennial concentrations exceed (bold values) for the Christmas tree crushed, compost + horse manure, Copoflora, Fibralgo and/or flax straw.

\begin{tabular}{|c|c|c|c|c|c|c|}
\hline & \multicolumn{3}{|c|}{ Cadmium } & \multicolumn{3}{|l|}{ Zine } \\
\hline Maximum concentration & $3 \mathrm{ppm}$ & $45 \mathrm{~g} / \mathrm{ha}$ & $150 \mathrm{~g} / \mathrm{ha}$ & $600 \mathrm{ppm}$ & $9000 \mathrm{~g} / \mathrm{ha}$ & $30,000 \mathrm{~g} / \mathrm{ha}$ \\
\hline Crushed tree fellings & 0.09 & 7.33 & 73.29 & 11.3 & 887.31 & 8873.09 \\
\hline Crushed bamboo & 0.16 & 4.9 & 48.96 & 22.29 & 681.96 & 6819.62 \\
\hline Various crushed leaves & 0.01 & 0.13 & 1.29 & 65.34 & 844.72 & 8447.24 \\
\hline Crushed plane leaves & 0.17 & 2.72 & 27.21 & 72.94 & 1167.5 & 11675.00 \\
\hline Crushed Sophora prunings & 0.07 & 5.13 & 51.3 & 15.93 & 1167.35 & 11673.49 \\
\hline Crushed Lime prunings & 0.15 & 4.58 & 45.78 & 20.04 & 611.92 & 6116.23 \\
\hline Various crushed prunings & 0.1 & 6.4 & 63.98 & 11.00 & 727.99 & 7279.94 \\
\hline Compost + Horse manure & 0.17 & 19.4 & 194.00 & 105.07 & 11990.08 & 119900.84 \\
\hline Recycled wood chips & $\underline{0.23}$ & 0.98 & 9.83 & 79.76 & 341.02 & 3410.22 \\
\hline Copoflora $C$ & $\underline{0.92}$ & 56.21 & 562.1 & 189.53 & 11643.09 & 116430.91 \\
\hline Buckwheat husks & 0.15 & 0.57 & 5.66 & 49.72 & 187.49 & 1874.94 \\
\hline Horse manure & 0.03 & 0.68 & 6.78 & 78.42 & 1772.71 & 17727.1 \\
\hline Grass straw & 0.02 & 0.21 & 2.07 & 10.14 & 105.1 & 1051.00 \\
\hline Barley straw & 0.2 & 2.02 & 20.22 & 26.59 & 275.69 & 2756.86 \\
\hline Hempe flakes & 0.14 & 7.27 & 72.68 & 14.43 & 749.14 & 7491.42 \\
\hline Flax flakes & $\underline{0.77}$ & 26.51 & 265.13 & 14.02 & 484.95 & 4849.53 \\
\hline Mowing grass & 0.09 & 0.62 & 6.17 & 68.24 & 485.98 & 4859.81 \\
\hline
\end{tabular}




\section{Table 4}

Effect of mineral fertilizer and different doses of MSW-compost, ADR and SMS on total biomass for different crops growing during the experiment. Within treatments columns values with no letter in common differ significantly at $\mathrm{P} \leq 0.05$ (Tukey HSD test).

\begin{tabular}{|c|c|c|c|c|c|c|}
\hline \multirow{3}{*}{$\begin{array}{l}\text { Matrix } \\
\begin{array}{l}\text { Crop } \\
\text { year } \\
\text { (t/ha) }\end{array}\end{array}$} & \multicolumn{2}{|l|}{ MSW } & \multicolumn{2}{|l|}{$\mathrm{ADR}$} & \multicolumn{2}{|l|}{ SMS } \\
\hline & tomato & late chicory & late cauliflower & late chicory & lettuce & leek \\
\hline & 2007 & 2010 & 2009 & 2010 & 2014 & 2015 \\
\hline T0 & $253 \mathrm{a}$ & $27,3 \mathrm{ab}$ & $56,4 \mathrm{~b}$ & $27,2 \mathrm{c}$ & 33,3 a & $20,9 \mathrm{~b}$ \\
\hline TMIN & $218 \mathrm{a}$ & $49,5 \mathrm{a}$ & 83,1 a & 59,8 a & $41,4 \mathrm{ab}$ & $31,3 \mathrm{a}$ \\
\hline T50 & $225 \mathrm{a}$ & $35,9 \mathrm{ab}$ & $69,1 \mathrm{ab}$ & 56,9 a & $45,5 \mathrm{a}$ & $31,7 \mathrm{a}$ \\
\hline T75 & - & - & $74,8 \mathrm{ab}$ & $48,8 \mathrm{ab}$ & - & - \\
\hline $\mathrm{T} 100$ & $225 \mathrm{a}$ & $24,4 \mathrm{ab}$ & $75,0 \mathrm{ab}$ & $34,1 \mathrm{bc}$ & $43,6 \mathrm{a}$ & $33,4 \mathrm{a}$ \\
\hline T200 & $224 \mathrm{a}$ & $16,3 \mathrm{~b}$ & - & - & - & - \\
\hline
\end{tabular}



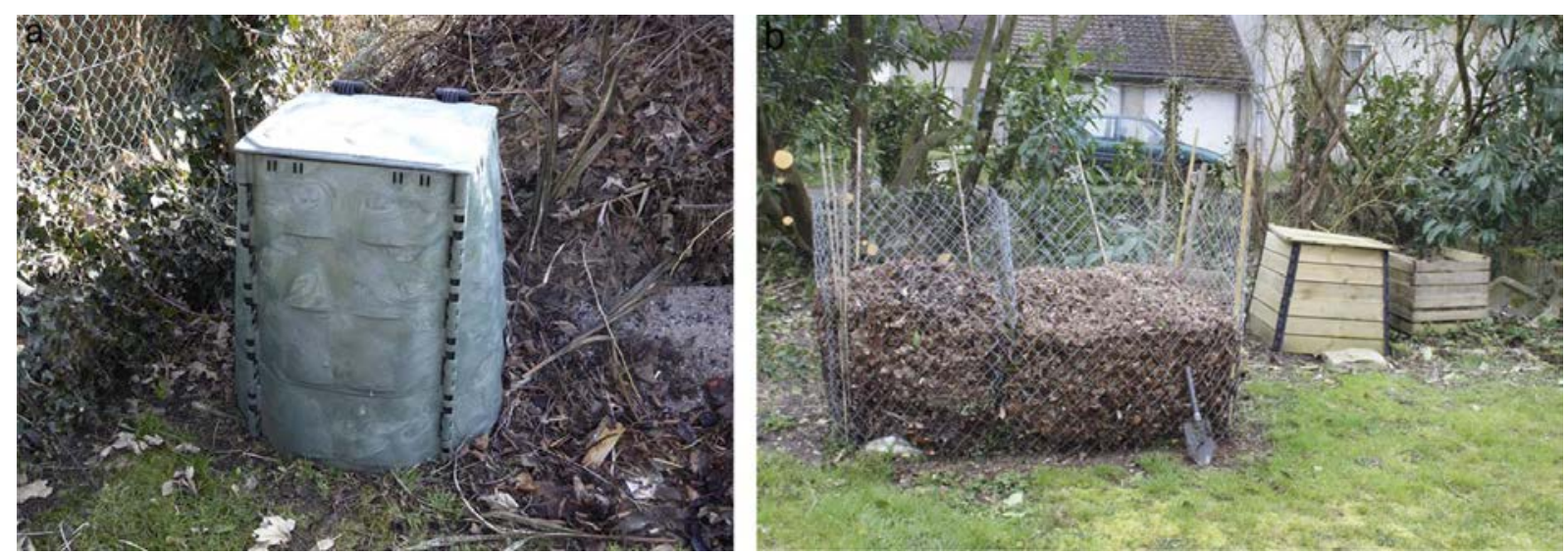

Fig. 1 

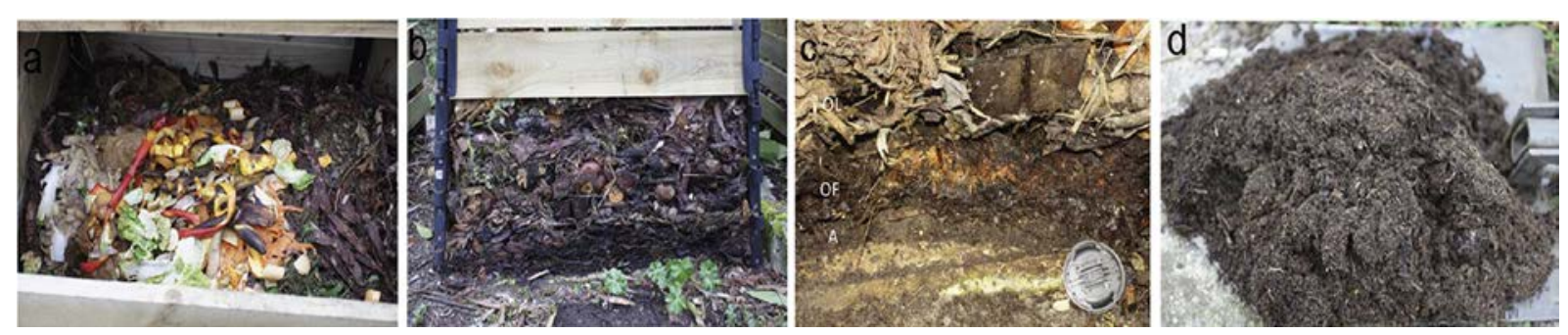

Fig. 2 

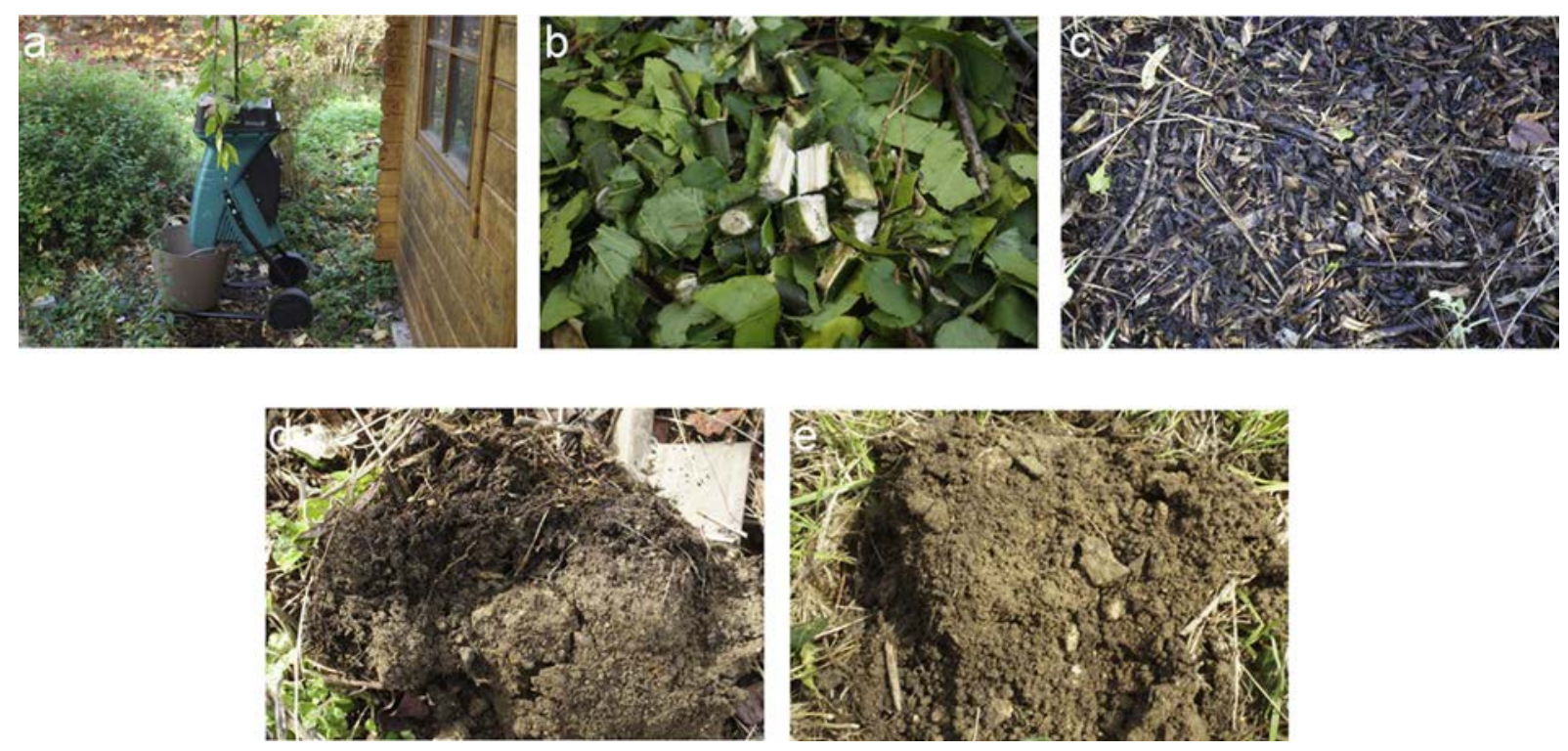

Fig. 3 


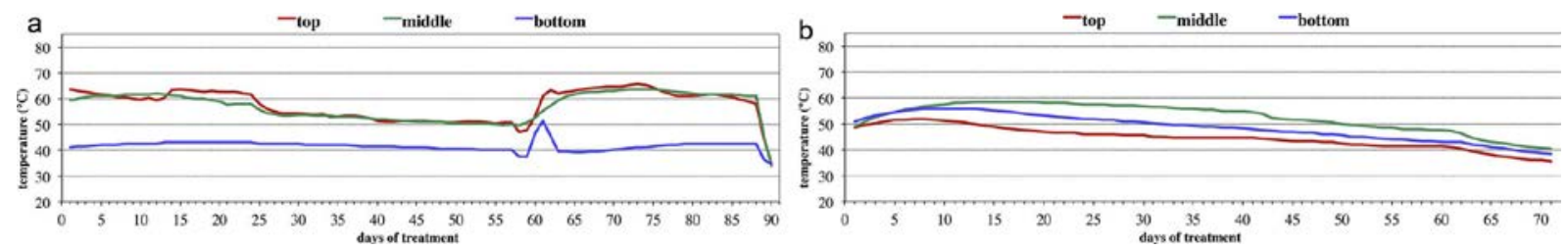

Fig. 4 


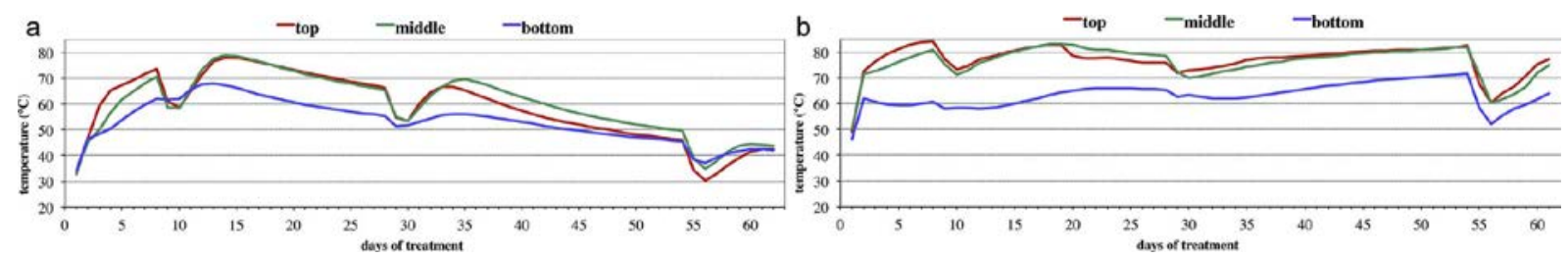

Fig. 5 

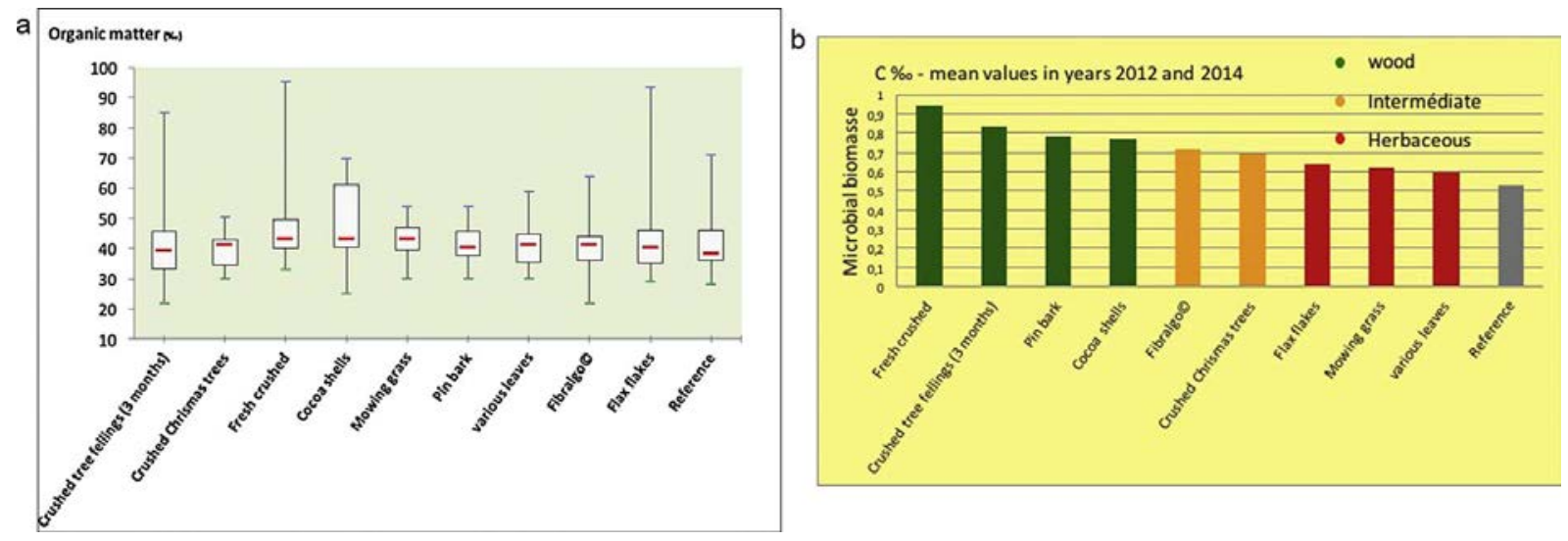

Fig. 6 


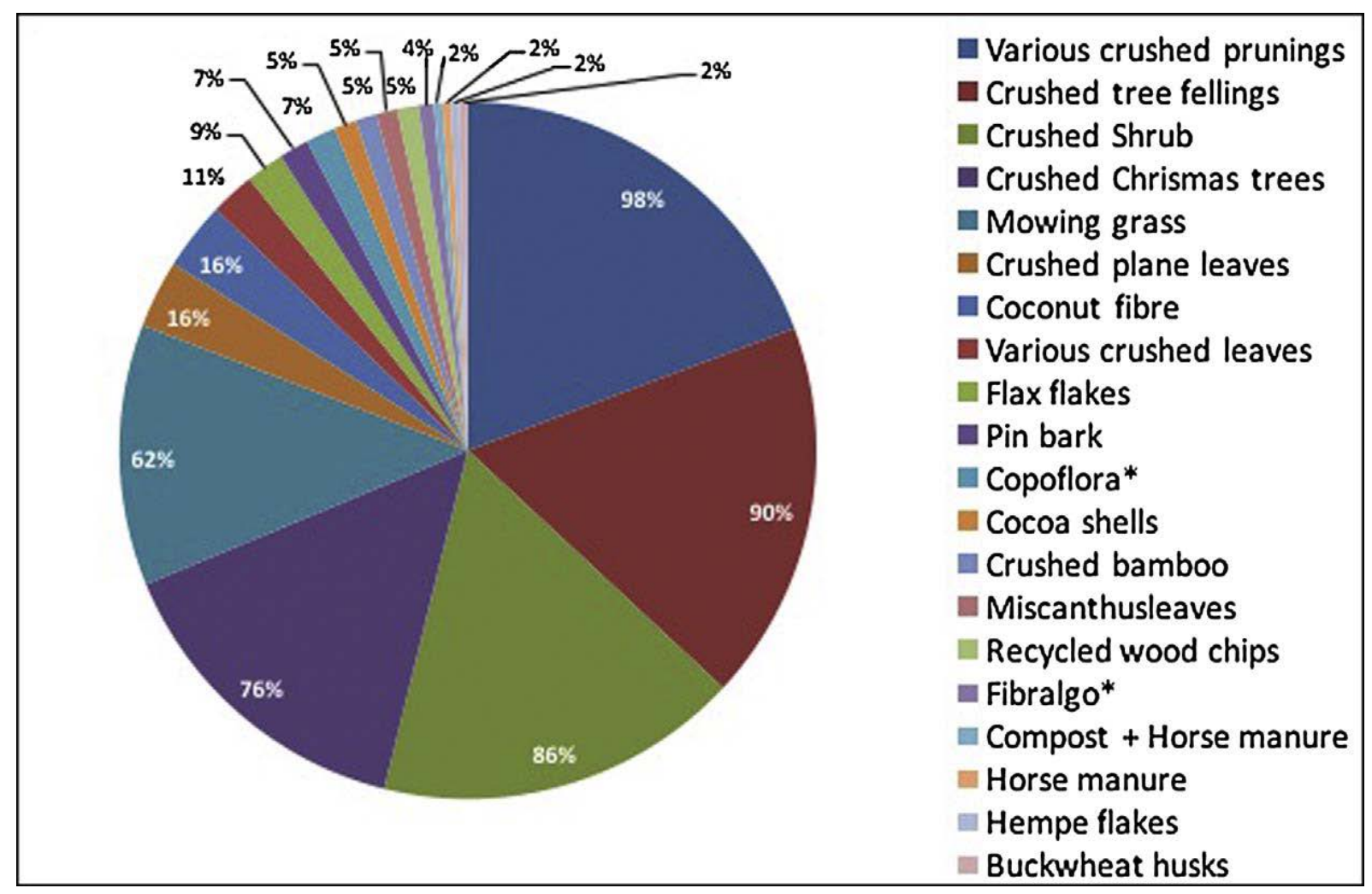

Fig. 7 


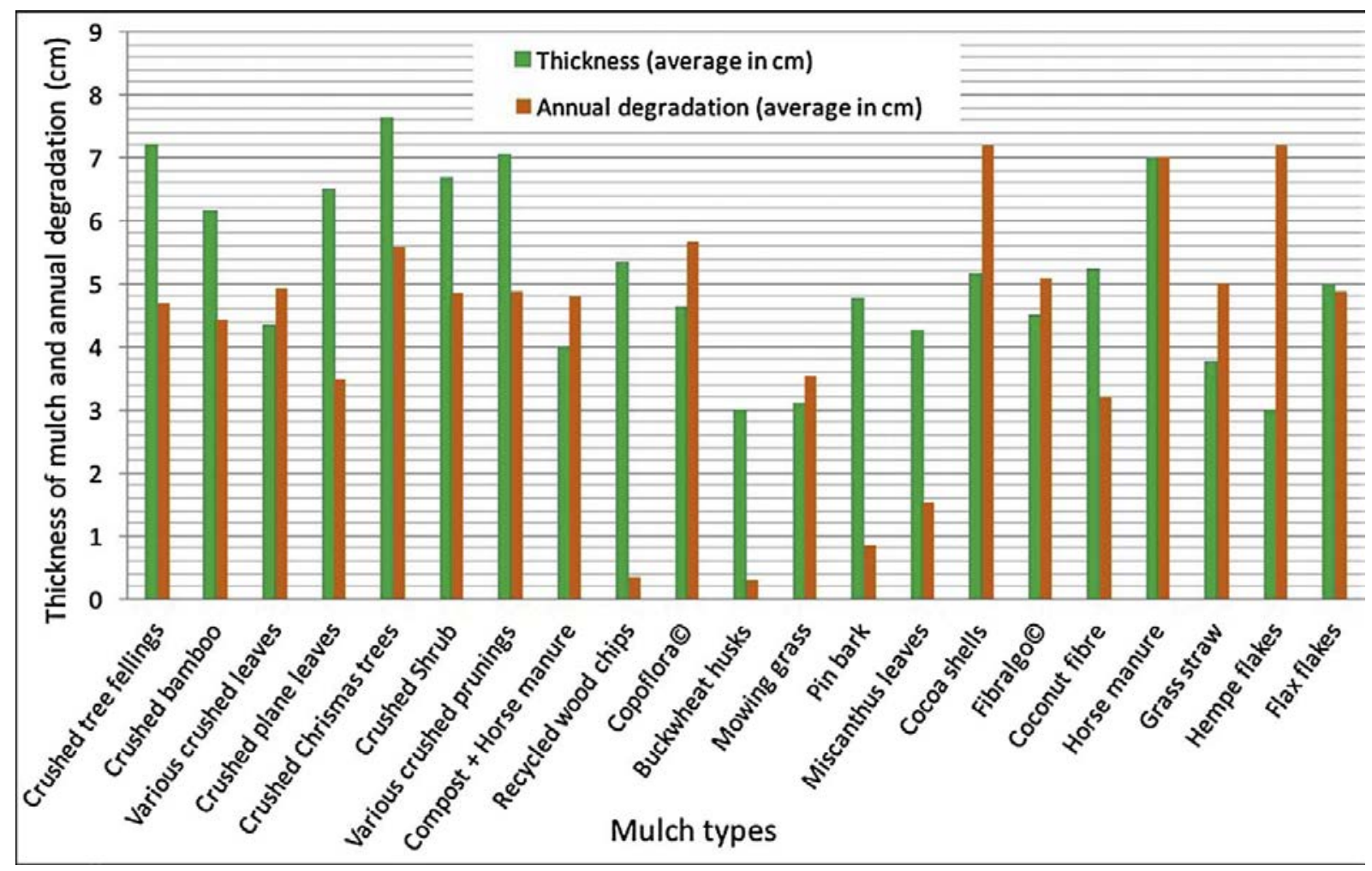

Fig. 8 


\begin{tabular}{|c|c|c|c|c|c|c|c|c|c|c|}
\hline & & \multicolumn{4}{|c|}{$\begin{array}{l}\text { Bed of perennial or summer flowers } \\
\text { (input in } \mathrm{kg} / \mathrm{ha} / \mathrm{yr} \text { ) }\end{array}$} & \multicolumn{4}{|c|}{$\begin{array}{l}\text { Clump of various shrubs } \\
\text { (input in } \mathrm{kg} / \mathrm{ha} / \mathrm{yr} \text { ) }\end{array}$} & \\
\hline \multirow{2}{*}{\multicolumn{2}{|c|}{ Theoretical outputs }} & $\mathrm{N}$ & $\mathbf{P}$ & $\mathrm{K}$ & $\mathrm{Mg}$ & $\mathrm{N}$ & $\mathbf{P}$ & $\mathrm{K}$ & $\mathrm{Mg}$ & \\
\hline & & 60 & 85 & 150 & 24 & 50 & 15 & 40 & 4 & \\
\hline \multirow{2}{*}{ Mulch types } & \multirow{2}{*}{$\begin{array}{c}\text { Degraded } \\
\text { mass } \mathrm{t} / \mathrm{ha} / \mathrm{yr}\end{array}$} & & & & & & & & & \\
\hline & & $\mathbf{N}$ & P2O5 & K2O & $\mathrm{MgO}$ & $\mathbf{N}$ & P2O5 & K2O & $\mathrm{MgO}$ & \\
\hline Crushed tree fellings & 79 & 188 & 38 & 183 & 96 & 188 & 38 & 183 & 96 & \\
\hline Crushed bamboo & 31 & 176 & 21 & 28 & 30 & 176 & 21 & 28 & 30 & \\
\hline Various crushed leaves & 13 & 173 & 38 & 92 & 40 & 173 & 38 & 92 & 40 & \\
\hline Crushed plane leaves & 16 & 139 & 23 & 25 & 39 & 139 & 23 & 25 & 39 & \\
\hline Crushed Christmas trees & 67 & 880 & 111 & 247 & 143 & 880 & 111 & 247 & 143 & \\
\hline Shredded shrubs & 38 & 278 & 56 & 187 & 53 & 278 & 56 & 187 & 53 & \\
\hline Crushed sophora prunings & 73 & 909 & 80 & 168 & 71 & 909 & 80 & 168 & 71 & \\
\hline Crushed lime prunings & 31 & 229 & 29 & 218 & 44 & 229 & 29 & 218 & 44 & \\
\hline Various crushed prunings & 66 & 351 & 50 & 199 & 83 & 351 & 50 & 199 & 83 & \\
\hline Compost + horse manure & 114 & 1061 & 599 & 1077 & 785 & 1061 & 599 & 1077 & 785 & \\
\hline Recycled wood chips & 4 & 20 & 4 & 2 & 4 & 20 & 4 & 2 & 4 & \\
\hline Copoflora & 61 & 399 & 73 & 285 & 191 & 399 & 73 & 285 & 191 & \\
\hline Buckwheat husks & 4 & 82 & 12 & 20 & 28 & 82 & 12 & 20 & 28 & \\
\hline Pin bark & 16 & 30 & 1 & 6 & 18 & 30 & 1 & 6 & 18 & \\
\hline Miscanthus leaves & 12 & 60 & 11 & 23 & 14 & 60 & 11 & 23 & 14 & \\
\hline Cocoa shells & 20 & 505 & 107 & 624 & 164 & 505 & 107 & 624 & 164 & \\
\hline Fibralgo* & 49 & 364 & 120 & 448 & 261 & 364 & 120 & 448 & 261 & \\
\hline Coconut fiber & 21 & 120 & 11 & 83 & 50 & 120 & 11 & 83 & 50 & \\
\hline Horse manure & 23 & 294 & 167 & 419 & 111 & 294 & 167 & 419 & 111 & \\
\hline Grass straw & 10 & 48 & 4 & 119 & 15 & 48 & 4 & 119 & 15 & \\
\hline Barley straw & 10 & 100 & 34 & 187 & 15 & 100 & 34 & 187 & 15 & \\
\hline Hemp flakes & 52 & 535 & 72 & 459 & 99 & 535 & 72 & 459 & 99 & \\
\hline Flax flakes & 35 & 96 & 17 & 79 & 33 & 96 & 17 & 79 & 33 & \\
\hline \multirow[t]{7}{*}{ Mowing grass } & 7 & 237 & 60 & 271 & 46 & 237 & 60 & 271 & 46 & \\
\hline & & & & & & & & & & \\
\hline & & & \multicolumn{3}{|c|}{$<70 \%$ requirements (Weak) } & & \multicolumn{4}{|c|}{$70<$ requirements $<100 \%$ (Optimum) } \\
\hline & & & & & & & & & & \\
\hline & & & \multicolumn{3}{|c|}{$100<$ requirements < 200\% (High) } & & \multicolumn{4}{|c|}{$300<$ requirements $<1000 \%$ (Very high) } \\
\hline & & & & & & & & & & \\
\hline & & & \multicolumn{3}{|c|}{$>1000$ requirements (Excessive) } & & & & & \\
\hline
\end{tabular}

Fig. 9 


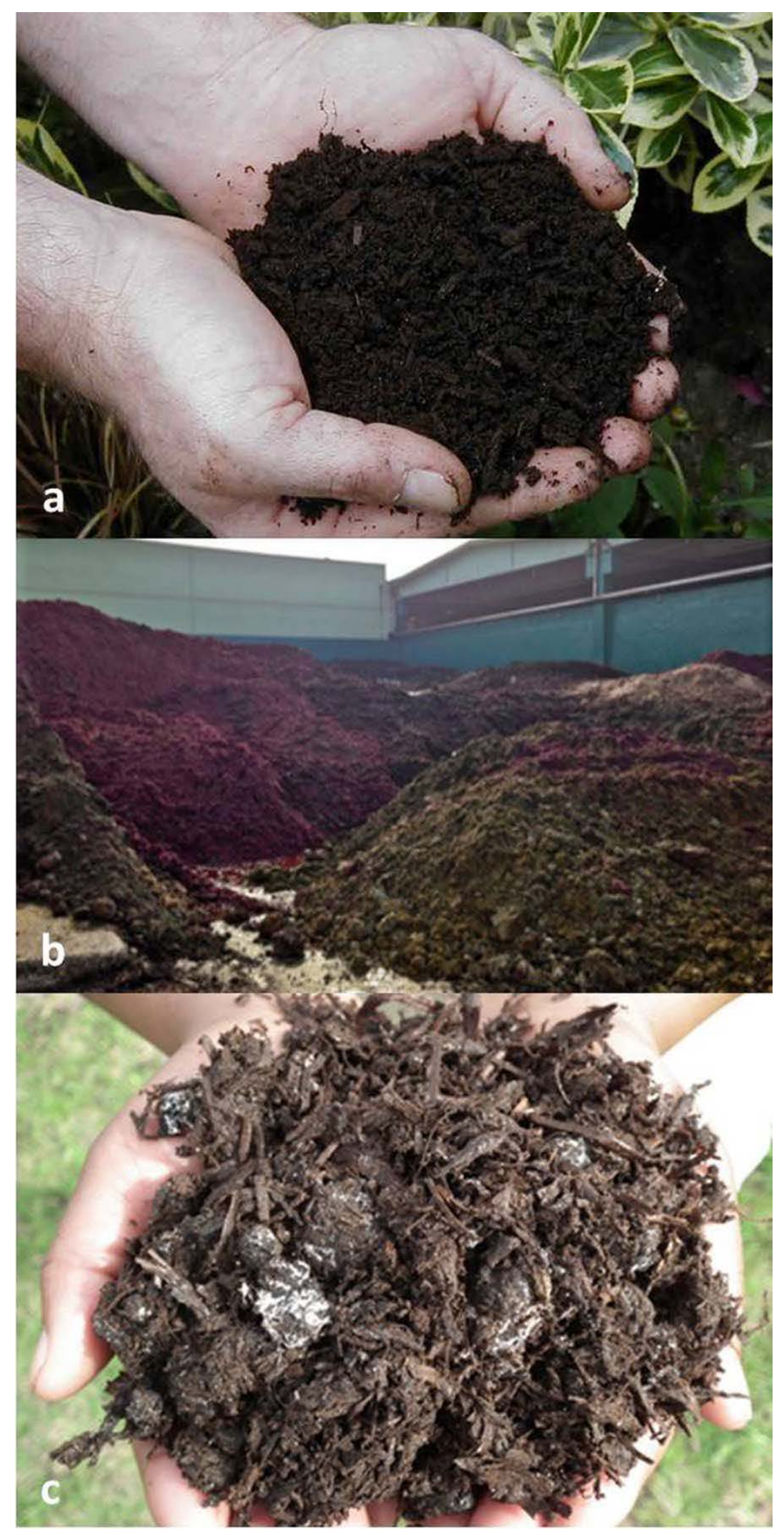

Fig. 10 


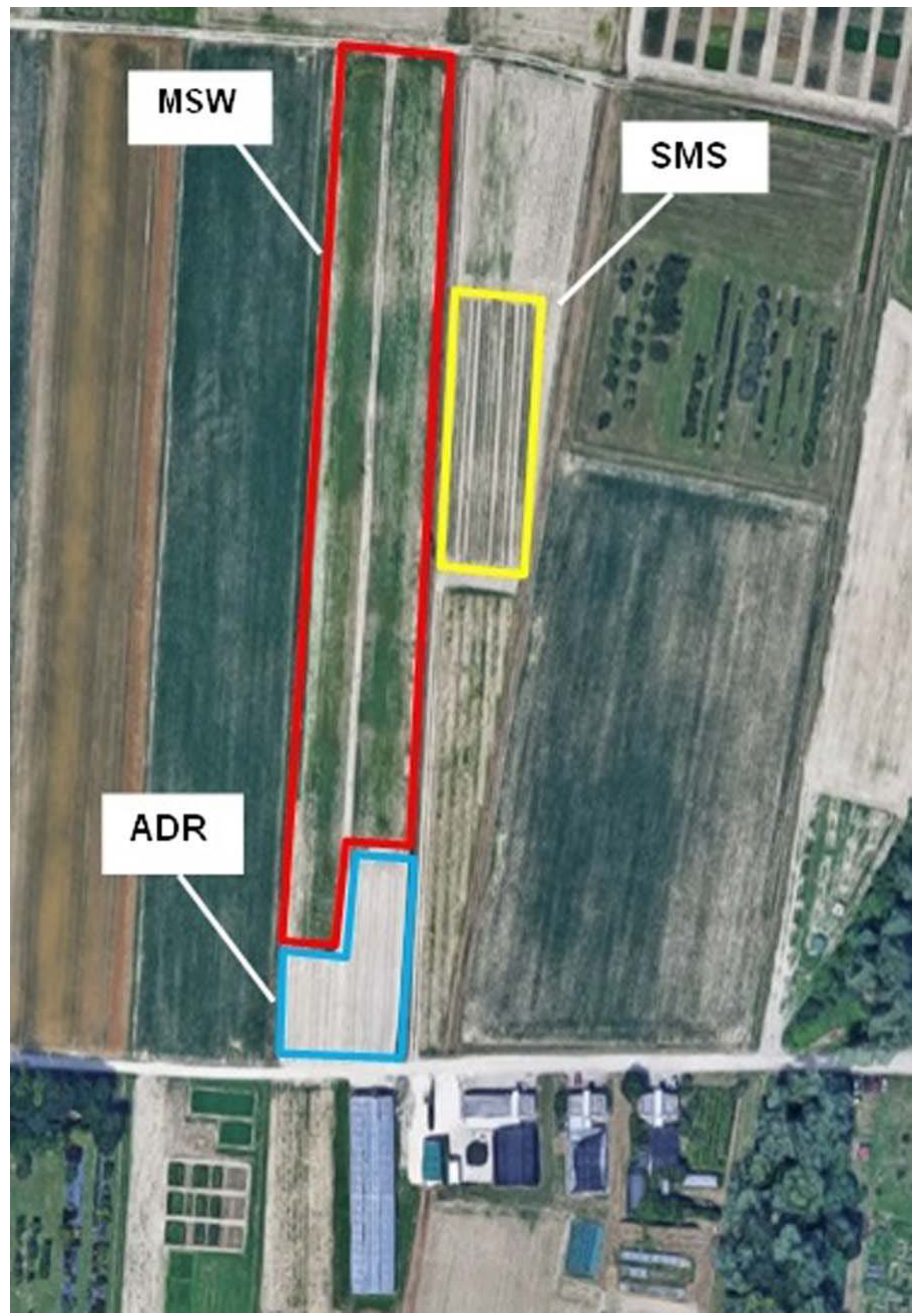

Fig. 11 


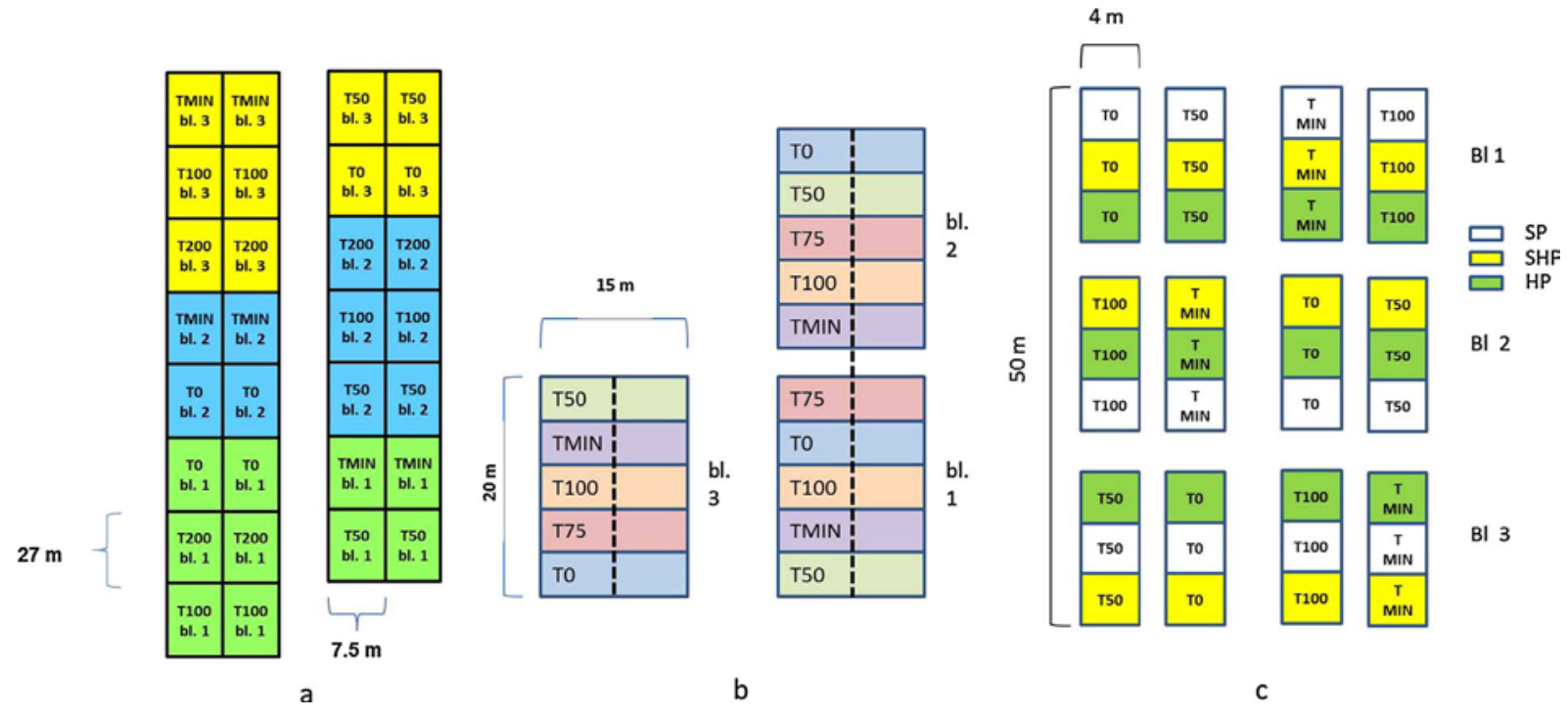

Fig. 12 


\section{a) MSW}

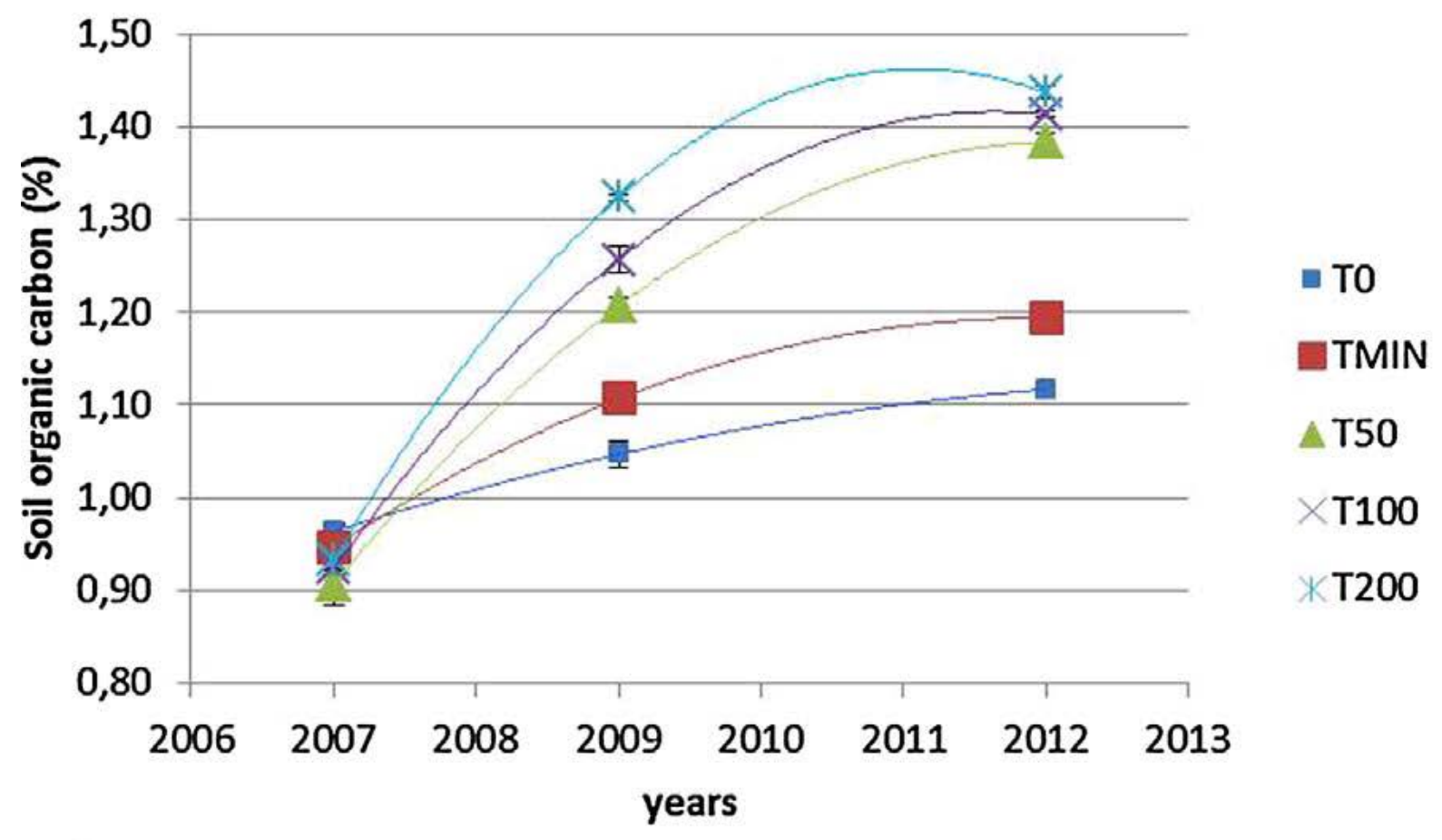

b) ADR

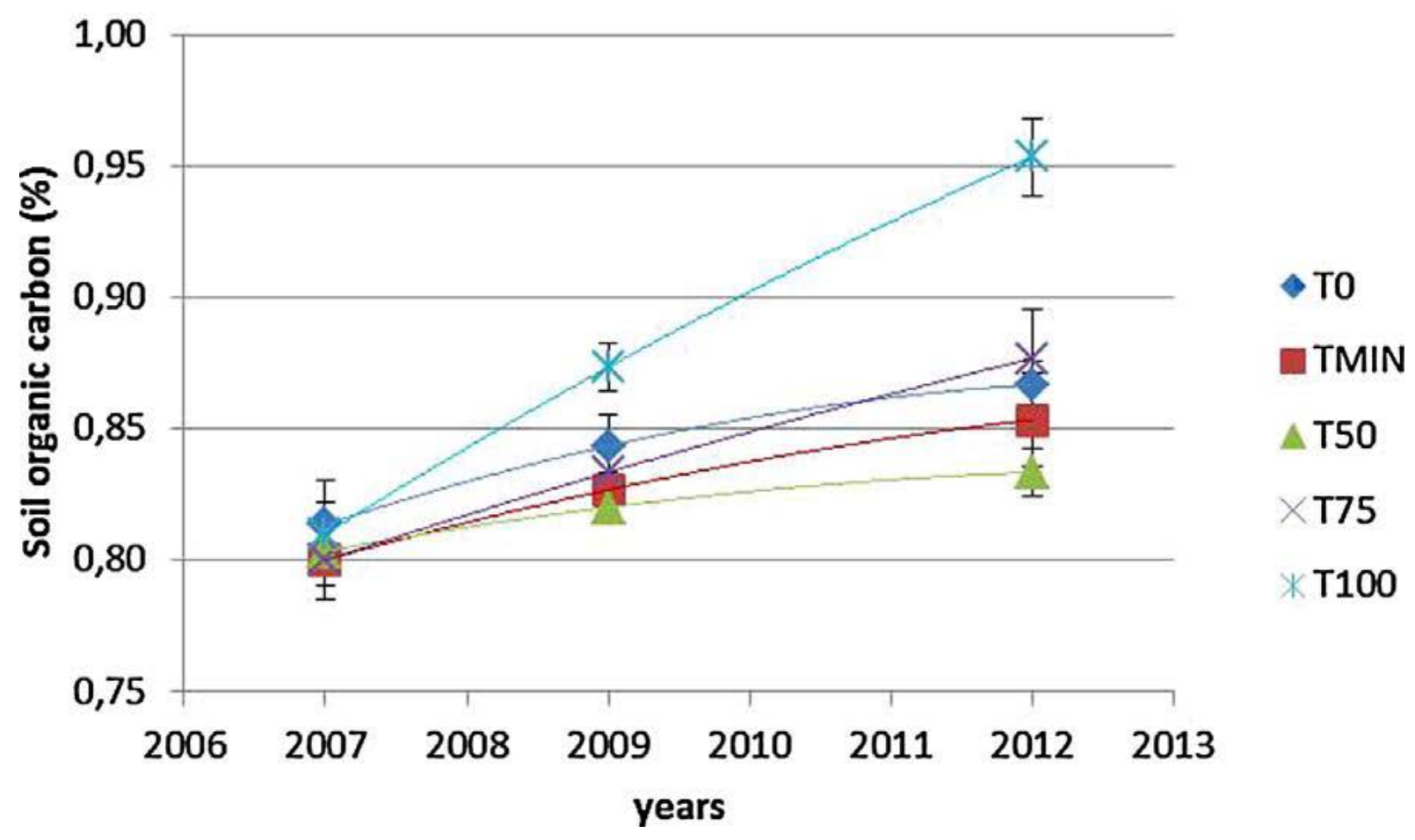

Fig. 13 


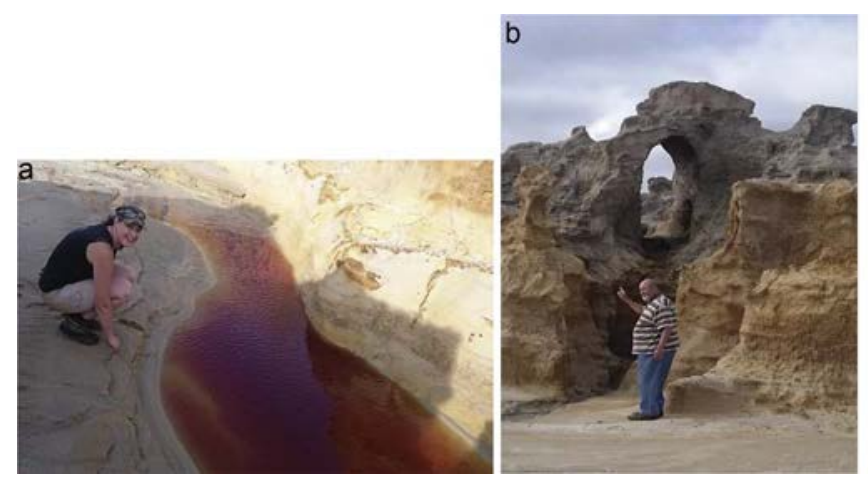

C Microbial activity of different natural soils and tailings materials

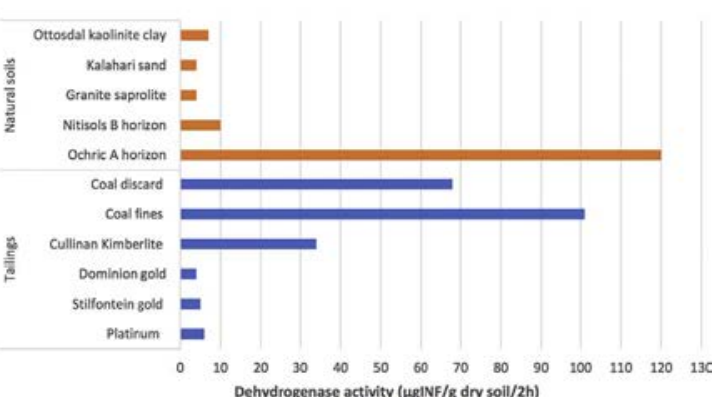

Fig. 14 